\title{
openheart Subclinical magnesium deficiency: a principal driver of cardiovascular disease and a public health crisis
}

\author{
James J DiNicolantonio, ${ }^{1}$ James H O’Keefe, ${ }^{1}$ William Wilson ${ }^{2}$
}

To cite: DiNicolantonio JJ, O'Keefe JH, Wilson W. Subclinical magnesium deficiency: a principal driver of cardiovascular disease and a public health crisis. Open Heart 2018;5:e000668. doi:10.1136/ openhrt-2017-000668

Received 2 June 2017 Revised 6 October 2017 Accepted 7 November 2017

CrossMark

${ }^{1}$ Department of Preventive Cardiology, Saint Luke's Mid America Heart Institute, Kansas City, Missouri, USA

${ }^{2}$ Hospital Medicine, Lahey Hospital \& Medical Center, Burlington, Massachusetts, USA

Correspondence to Dr James J DiNicolantonio; jjdinicol@gmail.com

\section{ABSTRACT}

Because serum magnesium does not reflect intracellular magnesium, the latter making up more than $99 \%$ of total body magnesium, most cases of magnesium deficiency are undiagnosed. Furthermore, because of chronic diseases, medications, decreases in food crop magnesium contents, and the availability of refined and processed foods, the vast majority of people in modern societies are at risk for magnesium deficiency. Certain individuals will need to supplement with magnesium in order to prevent suboptimal magnesium deficiency, especially if trying to obtain an optimal magnesium status to prevent chronic disease. Subclinical magnesium deficiency increases the risk of numerous types of cardiovascular disease, costs nations around the world an incalculable amount of healthcare costs and suffering, and should be considered a public health crisis. That an easy, cost-effective strategy exists to prevent and treat subclinical magnesium deficiency should provide an urgent call to action.

\section{MAGNESIUM IN HUMAN BIOLOGY}

'Magnesium is the seventh most abundant element in the Earth's crust by mass or molarity...In vertebrates, magnesium is extremely abundant and it is the second most common intracellular cation (potassium being the first). Extracellular magnesium accounts for only $\sim 1 \%$ of total body magnesium, which is found primarily in serum and red blood cells'.

Magnesium is the fourth most common cation in our body, the second most common intracellular cation and the most common intracellular divalent cation. ${ }^{2}$ The human body contains around $25 \mathrm{~g}$ of magnesium. ${ }^{3}$ Magnesium is necessary for the functioning of over 300 enzymes in human, ${ }^{4}$ with $90 \%$ of total body magnesium being contained in the muscles and bones $(\sim 27 \%$ and $\sim 63 \%$, respectively), $90 \%$ of which is bound and with only $10 \%$ being free. $^{5}$ In the serum, $32 \%$ of magnesium is bound to albumin, whereas $55 \%$ is free. ${ }^{5}$

Some of the main functions of magnesium in human biology include the maintenance of ionic gradients (keeping intracellular sodium and calcium low and potassium high), cellular and tissue integrity, mitochondrial oxidative phosphorylation (ATP production and activation), and DNA, RNA and protein synthesis and integrity. ${ }^{36}$

The elimination of magnesium is mainly controlled by the kidneys, increasing in the urine when there is magnesium surplus and falling to just $1 \mathrm{mEq}$ of magnesium $(\sim 12 \mathrm{mg})$ during deficits. ${ }^{3}$ However, despite renal conservation, magnesium can be pulled from the bone (as well as muscles and internal organs) in order to maintain normal serum magnesium levels when intakes are low. ${ }^{78}$ Thus, a normal serum magnesium level does not rule out magnesium deficiency, which predisposes to osteopaenia, osteoporosis and fractures.

An excess of heavy metals due to soil contamination and a lack of minerals due to soil erosion also may predispose to micronutrient deficits. ${ }^{9}$ The importance of the mineral content of soil and water, once greatly appreciated, think low iodine levels in soil and the increased prevalence of goitre, has all but been forgotten. ${ }^{10}$ Furthermore, refined foods are depleted of magnesium during their processing. ${ }^{11}$ In order to prevent chronic diseases, we need to change our mindset away from exclusively treating acute illness and instead focus more on treating the underlying causes of chronic diseases, such as magnesium deficiency.

There are two types of nutrient deficiencies, frank deficiencies (such as scurvy from ascorbic acid deficiency or goitre from iodine deficiency) and subclinical deficiencies (a clinically silent reduction in physiological, cellular and/or biochemical functions). It is the latter that is most concerning as it is hard to diagnose and predisposes to numerous chronic diseases. And while both result in negative health consequences, the former has obvious symptoms (hence frank deficiency), whereas the latter may have negative or variable health effects that are not so apparent (eg, vascular calcification). The evidence 
in the literature suggests that subclinical magnesium deficiency is rampant and one of the leading causes of chronic diseases including cardiovascular disease and early mortality around the globe, and should be considered a public health crisis. ${ }^{12-14}$

\section{MAGNESIUM INTAKE}

'The homeostatic mechanisms to regulate magnesium balance were developed millions of years ago. Investigations of the macro- and micro-nutrient supply in Paleolithic nutrition of the former hunter/gatherer societies showed a magnesium uptake with the usual diet of about $600 \mathrm{mg}$ magnesium/day, much higher than today'. Our homeostatic mechanisms and genome are still the same as with our ancestors in the Stone Age. This means our metabolism is best adapted to a high magnesium intake. ${ }^{5}$

In developed countries, the average intake of magnesium is slightly over $4 \mathrm{mg} / \mathrm{kg} /$ day. ${ }^{15}$ More than a quarter of obese and non-obese youth have inadequate intakes of magnesium (27\% and 29\%, respectively). The authors of a study concluded: 'Even though children may consume an excess of energy, they may not be meeting all of their micronutrient needs'. ${ }^{16}$ In other words, children are overfed and undernourished. One expert has argued that a typical Western diet may provide enough magnesium to avoid frank magnesium deficiency, but it is unlikely to maintain high-normal magnesium levels and provide optimal risk reduction from coronary artery disease and osteoporosis. That is, "Various studies have shown that at least $300 \mathrm{mg}$ magnesium must be supplemented to establish significantly increased serum magnesium concentrations... ${ }^{5}$ In other words, most people need an additional $300 \mathrm{mg}$ of magnesium per day in order to lower their risk of developing numerous chronic diseases. So while the recommended daily allowance (RDA) for magnesium (between 300 and $420 \mathrm{mg}$ /day for most people) may prevent frank magnesium deficiency, it is unlikely to provide optimal health and longevity, which should be the ultimate goal.

Importantly, much of the population may not even be meeting the RDA for magnesium. For example, the average magnesium intake in men and women in Taiwan is only $250 \mathrm{mg}$ and $216 \mathrm{mg}$, respectively, or $68 \%-70 \%$ of the recommended dietary reference intake. ${ }^{17}$ The authors of the study concluded: 'Taiwanese elderly persons had suboptimal levels of dietary magnesium intake, which although may be sufficient to avoid overt magnesium deficiency, may not be sufficient to reduce the risk of diabetes in the elderly'. ${ }^{17}$ The National Nutrition Survey in Japan found that for people 15-49 years old the intake of magnesium was below the Japanese RDA. ${ }^{18}$ Moreover, around half $(48 \%)$ of the US population consumes less than the recommended amount of magnesium from food. ${ }^{19}$ The US Department of Agriculture states that the average magnesium intake in women and men is $228 \mathrm{mg} /$ day and $323 \mathrm{mg} /$ day, respectively. Based on these data, one group of authors noted: 'These intake levels suggest that a substantial number of people may be at risk for $\mathrm{Mg}$ deficiency, especially if concomitant disorders and/ or medications place the individual at further risk for $\mathrm{Mg}$ depletion'. 7 The most recent published review on magnesium concluded: 'Approximately $50 \%$ of Americans consume less than the Estimated Average Requirement (EAR) for magnesium, and some age groups consume substantially less' ${ }^{20}$

Lakshmanan et al collected daily food records for 1 year in 34 men and women. They found that the mean magnesium intake was $323 \mathrm{mg} /$ day and $234 \mathrm{mg} /$ day in men and women, respectively (around $4 \mathrm{mg} / \mathrm{kg} /$ day). Despite this level of intake, the overall patient population was in negative magnesium balance $(-32$ and $-25 \mathrm{mg}$ /day, respectively)..$^{21}$ Moreover, $75 \%$ of women consumed less than the RDA $(300 \mathrm{mg} /$ day $)$ and only one out of the eighteen women were in equilibrium. Considering that the average intake of magnesium in the USA is around $228 \mathrm{mg}$ /day in women and $266 \mathrm{mg} /$ day in men, ${ }^{12}$ a large percentage of Americans may be at risk of negative magnesium balance. Indeed, 'Only American diets containing more than 3000 $\mathrm{kcal} /$ day may provide $300 \mathrm{mg}$ or more magnesium,. Another long-term study lasting 50 weeks found that somewhere between $180 \mathrm{mg}$ and $320 \mathrm{mg}$ of magnesium/ day is required in order to maintain positive magnesium balance. ${ }^{22}$ And since many individuals may be consuming below $320 \mathrm{mg} /$ day of magnesium, this poses a major public health threat.

The data are consistent around the world that magnesium intake may be inadequate. Indeed, the intake of magnesium in Germany was determined to be only $200 \mathrm{mg}$ for women and $250 \mathrm{mg}$ for men. ${ }^{523} \mathrm{In}$ Kiev a study on 780 men aged $20-59$ found that the overall population consumed insufficient magnesium from food rations ( $10 \%$ less than the recommended value). The authors also found a correlation between the low magnesium consumption in food and the prevalence of risk factors for ischaemic heart disease, such as hyperlipoproteinaemia, arterial hypertension and body weight. ${ }^{24}$ In 2004, Durlach concluded: 'About 20\% of the population consumes less than two-thirds of the RDA for Mg. Women, particularly, have low intakes. For example, in France, $23 \%$ of women and $18 \%$ of men have inadequate intakes. $\mathrm{Mg}$ deficiency during pregnancy can induce maternal, fetal, and pediatric consequences that might last throughout life' ${ }^{25}$ The median magnesium intake in an elderly population (832 subjects aged 70 years or older) in Southern France was also found to be below the RDA. ${ }^{26}$ Another French study on 2373 subjects (4-82 years of age) noted that $71.7 \%$ of men and $82.5 \%$ of women had an inadequate magnesium intake. ${ }^{27}$

\section{MAGNESIUM DEFICIENCY}

'Hypomagnesemia is a relatively common occurrence in clinical medicine. That it often goes unrecognized is due to the fact that magnesium levels are rarely evaluated since few clinicians are aware of the many clinical 
states in which deficiency, or excess, of this ion may occur'. ${ }^{28}$

In developed countries, older data estimated that the prevalence of marginal magnesium deficit is $15 \%-20 \%$ of the population. ${ }^{15}$ This corroborates more recent data indicating that around $10 \%-30 \%$ of a given population has subclinical magnesium deficiency based on serum magnesium levels $<0.80 \mathrm{mmol} / \mathrm{L}^{29}$ The 2006 National Health and Nutrition Survey found low serum concentrations of magnesium in $36.3 \%$ and $31 \%$ of female and male Mexican adults, respectively. ${ }^{30}$ The authors of the study concluded: 'Low serum concentrations of...magnesium are published for the first time and show significant prevalence of deficiencies', ${ }^{30}$ and up to $20 \%$ of the general population has low serum magnesium levels. ${ }^{31}$ A systematic review of 37 articles discovered that magnesium deficiency was a possible public health concern for older adults. ${ }^{32}$

Magnesium deficiency has been found in $84 \%$ of postmenopausal women with osteoporosis diagnosed by low magnesium trabecular bone content and Thoren's magnesium load test. ${ }^{33}$ Among apparently healthy university students in Brazil, $42 \%$ were found to have subnormal magnesium status (based on plasma or erythrocyte magnesium levels). ${ }^{13}$ The average magnesium intake was only around $215 \mathrm{mg} /$ day. Magnesium depletion has been found in $75 \%$ and $30.8 \%$ of patients with poorly controlled type 2 diabetes based on serum and intracellular magnesium status, respectively. ${ }^{34}$

Magnesium deficiency can be present despite normal serum magnesium levels. ${ }^{6}$ Approximately $20 \%$ of 381 unselected elderly men and women (most of them in their 80s) were found to have low erythrocyte potassium and magnesium levels. The authors of the study concluded: 'This study underlines the large prevalence of magnesium and potassium deficiencies in the elderly'. ${ }^{35}$ Another study concluded: 'The commonly designated low limit of the normal range...is below levels that exist in patients with marginal deficiencies that can predispose to development of pathologic findings, so that the prevalence and importance of this disease is insufficiently considered...It is a statistical error to use the confidence limits of the normal population as the exclusion limit for those with abnormal Mg status'. ${ }^{36}$ In other words, our normal range of serum magnesium is inaccurate and that serum magnesium levels at the lower end of normal likely suggest marginal magnesium deficiency. ${ }^{29}$ Indeed, 'The magnesium content of the plasma is an unreliable guide to body stores: muscle is a more accurate guide to the body content of this intracellular cation'. ${ }^{37}$

Another study highlighting the discrepancy between serum and body magnesium levels concluded: 'Although serum-K and serum-Mg values in patients receiving long-term treatment for hypertension or incompensated heart disease usually are normal, muscle-Mg and muscle-K contents are reduced in around $50 \%$ of these patients...Evaluation of the $\mathrm{K}$ and $\mathrm{Mg}$ status during diuretic treatment should be preferentially based on tissue determinations. The muscle biopsy method is rapid, reliable and may reveal conditions of deficiency... oral supplements of $\mathrm{Mg}$ have proved to be adequate to restore the normal $\mathrm{K} / \mathrm{Mg}$ status'. ${ }^{38}$

Among critically ill postoperative patients, $36.5 \%$ were found to have magnesium deficiency based on ionised magnesium levels in red blood cells. ${ }^{39}$ In one study of patients from a medical intensive care unit (ICU), $65 \%$ had hypomagnesaemia. The author concluded: 'The prevalence of normomagnesemic $\mathrm{Mg}$ deficiency in critically ill patients may be even higher (than 65\%, my insertion) and may contribute to the pathogenesis of hypocalcemia, cardiac arrhythmias and other symptoms of $\mathrm{Mg}$ deficiency'. ${ }^{40}$ Finally, $6.9 \%-11 \%$ of hospitalised patients have been noted to have hypomagnesaemia on routine exam posing on unrecognised need. ${ }^{41}$

The overall incidence of hypomagnesaemia in one study was noted to be between $5 \%$ and $8 \%$ of the overall population, and in young women (aged 18-22) the incidence was approximately $20 \% .^{5}$ One of the largest studies, a cross-sectional study in an unselected population of more than 16000 subjects in Germany, found a prevalence of hypomagnesaemia (magnesium levels below $0.76 \mathrm{mmol} / \mathrm{L}$ ) of $14.5 \% .^{542}$ Over $15 \%$ of hospitalised elderly patients have been found with low serum magnesium levels. ${ }^{43}$ Another study noted: 'At ICU admission $52.5 \%$ had total hypomagnesemia and $13.5 \%$ total hypermagnesemia; with respect to the $\operatorname{Mg}(2+) 9.7 \%$ showed ionized hypomagnesemia and $23.6 \%$ ionized hypermagnesemia. Patients who developed ionized hypermagnesemia had higher mortality than patients without ionized hypermagnesemia development $(\mathrm{P}=0.04){ }^{,}{ }^{44}$ And it has been noted that 'Hypomagnesemia detected at the time of admission of acutely ill medical patients is associated with an increased mortality rate for both ward and medical ICU patients' ${ }^{45}$ Magnesium depletion is present in about half of all ICU patients. ${ }^{46}$ More than $50 \%$ of those hospitalised with either of the following conditions are likely to be magnesium-deficient based on an intravenous retention $>20 \%$ : hypertension, coronary artery disease, cerebrovascular event, gastrointestinal issues or alcoholism. ${ }^{47}$

Based on 183 peer-reviewed studies published from 1990 to 2008, one group of authors concluded: 'The perception that 'normal' serum magnesium excludes deficiency is common among clinicians. This perception is probably enforced by the common laboratory practice of highlighting only abnormal results. A health warning is therefore warranted regarding potential misuse of 'normal' serum magnesium because restoration of magnesium stores in deficient patients is simple, tolerable, inexpensive and can be clinically beneficial'. ${ }^{48}$

One study found that 10 out of 11 apparently healthy women were magnesium-deficient based on the oral magnesium load test. The authors concluded: 'The results showed there are more frequent deficiencies of magnesium in organisms than it is generally assumed'. ${ }^{49}$ Another study showed that $37.6 \%$ of patients with type 
2 diabetes and $10.9 \%$ of age-matched and sex-matched healthy controls have low plasma magnesium levels. ${ }^{50}$

Of patients with severe chronic airway obstruction, $11.6 \%$ have serum magnesium levels less than the lower normal limit. The authors of the study concluded: '...routine serum magnesium determination is recommended in patients with chronic obstructive lung disease taking diuretic drugs or corticosteroids, ${ }^{51}$

Hypomagnesaemia was identified in $47 \%$ of 1033 samples based on both routine magnesium determinations as well as physician-initiated requests for magnesium measurements. ${ }^{52}$ Importantly, only $10 \%$ of the hypomagnesaemia findings were found by physicianinitiated requests, underscoring the fact that low magnesium blood levels are an overlooked issue by medical doctors.

About $80 \%$ of patients with hypertension treated for at least 6 months with either hydrochlorothiazide or a single non-diuretic drug have been found to have magnesium depletion based on retention of a parenterally administered magnesium load. ${ }^{53}$ More troubling is that despite being magnesium-depleted, patients treated with hydrochlorothiazide had high normal serum magnesium. This study underlines how patients can have normal or even higher magnesium levels in the blood despite magnesium depletion. Another study confirmed these findings that 'thiazides induce a magnesium depletion not detectable by monitoring serum levels' ${ }^{54}$ There is a correlation between low magnesium bone concentrations and increased magnesium retention after an intravenous magnesium load, suggesting that magnesium is retained in the bone after the test. ${ }^{55}$

After several weeks of strenuous physical activity, serum magnesium can increase with no change in erythrocyte magnesium levels despite a reduction in mononuclear cell magnesium levels. The authors of a study concluded that the reduction in mononuclear cell magnesium content 'reflects a reduction in exchangeable magnesium body stores, and the onset of a magnesium deficiency state' ${ }^{56}$ This study also indicates that just $6-12$ weeks of strenuous physical activity can lead to magnesium deficiency. Another study concluded: 'Serum and urinary magnesium concentrations decrease during endurance running, consistent with the possibility of magnesium deficiency. This may be related to increased demand in skeletal muscle'. 57

One study found low levels of erythrocyte magnesium in 119 of $179(66 \%)$ patients admitted consecutively to the ICU. ${ }^{58}$ The prevalence of hypomagnesaemia at ICU admission has been estimated at around $51.3 \%$, with a prevalence of ionised hypomagnesaemia at ICU admission ranging between $14.4 \%$ and $22 \%{ }^{44}$

While a normal serum magnesium is considered to be $0.7-1 \mathrm{mmol} / \mathrm{L}$, the optimal serum magnesium concentration has been proposed to be $>0.80 \mathrm{mmol} / \mathrm{L} \cdot{ }^{59}$ Chronic latent magnesium deficiency has been defined as '...a serum magnesium concentration of between 0.75 and $0.849 \mathrm{mmol} / \mathrm{L}$ (within the reference interval), with a positive magnesium load test indicating magnesium deficiency'. ${ }^{14}$

\section{In summary}

'Abnormalities of serum Mg may be the most underdiagnosed serum electrolyte abnormality in clinical practice today. The incidence appears to range from $12.5 \%$ to $20 \%$ on routine determination'. ${ }^{41}$

\section{'NORMAL' SERUM MAGNESIUM LEVELS $0.75-0.95 \mathrm{mmol} / \mathrm{L}^{29}$}

- A serum magnesium $<0.82 \mathrm{mmol} / \mathrm{L}(2.0 \mathrm{mg} / \mathrm{dL})$ with a 24-hour urinary magnesium excretion of $40-80 \mathrm{mg} /$ day is highly suggestive of magnesium deficiency. ${ }^{29}$

- One group of experts has recommended magnesium supplementation in subjects experiencing symptoms that reflect magnesium deficiency if the serum level is below $0.9 \mathrm{mmol} / \mathrm{L},{ }^{36}$ with levels less than $0.8 \mathrm{mmol} / \mathrm{L}$ necessitating magnesium.

- Serum magnesium levels above $0.95 \mathrm{mmol} / \mathrm{L}$ may indicate hypermagnesaemia.

\section{DIETARY FACTORS AFFECTING MAGNESIUM STATUS}

'Although magnesium intakes have been gradually falling since the beginning of the century, there were sharply increased intakes of nutrients that increased its requirements [particularly high vitamin $\mathrm{D}$ and phosphorus intakes]...The major source of phosphorus derives from soft drinks that contain phosphoric acid, the consumption of which has been rising markedly in the last quarter of a century'. ${ }^{60}$

Since 1940 there has been a tremendous decline in the micronutrient density of foods. In the UK for example, there has been loss of magnesium in beef $(-4$ to $-8 \%)$, bacon $(-18 \%)$, chicken $(-4 \%)$, cheddar cheese $(-38 \%)$, parmesan cheese $(-70 \%)$, whole milk $(-21 \%)$ and vegetables $(-24 \%){ }^{61}$ The loss of magnesium during food refining/processing is significant: white flour $(-82 \%)$, polished rice $(-83 \%)$, starch $(-97 \%)$ and white sugar $(-99 \%) .{ }^{12}$ Since 1968 the magnesium content in wheat has dropped almost $20 \%$, which may be due to acidic soil, yield dilution and unbalanced crop fertilisation (high levels of nitrogen, phosphorus and potassium, the latter of which antagonises the absorption of magnesium in plants). ${ }^{62}$ One review paper concluded: 'Magnesium deficiency in plants is becoming an increasingly severe problem with the development of industry and agriculture and the increase in human population'. ${ }^{62}$ Processed foods, fat, refined flour and sugars are all devoid of magnesium, and thus our Western diet predisposes us to magnesium deficiency. Good dietary sources of magnesium include nuts, dark chocolate and unrefined whole grains.

Increased calcium and phosphorus intake also increases magnesium requirements and may worsen or precipitate magnesium deficiency. ${ }^{63-65}$ Dairy, especially cheese, has a very high phosphorus to magnesium $(\mathrm{Mg})$ ratio. For 
example, cheddar cheese has a phosphorus:magnesium ratio of $\sim 18$ and a calcium:magnesium ratio of $\sim 26,{ }^{66}$ whereas pumpkin seeds have a phosphorus:magnesium ratio of 0.35 and a calcium:magnesium ratio of $0.21{ }^{67}$ Some have argued that the optimal dietary calcium:magnesium ratio is close to $2: 1 .^{15}$

The amount of dietary magnesium required to maintain positive balance depends on numerous factors including the patient population as well as dietary and lifestyle choices. Indeed, magnesium balance decreases when calcium intake is over $10 \mathrm{mg} / \mathrm{kg} /$ day. ${ }^{21}$ Thus, the minimum required magnesium intake to maintain positive balance is not universal. Indeed, 'Magnesium, like other dietary components, interacts with several nutrients and its requirement is modified not only by their levels but also by their form or type. The American diet is low in calcium and fiber as well as in magnesium, and high in protein and phosphorus'. ${ }^{21}$ Excess calcium, phosphorus and vitamin D may also lead to increased magnesium loss increasing magnesium requirements. ${ }^{60}$

The phosphate to calcium ratio in the USA during 1932-1939 was approximately 1.2:1, rising to $4: 1$ in those who substituted the intake of soda for milk, but other data suggest that the phosphate:calcium ratio is around $1.5: 1{ }^{60}$ Nonetheless, the most dramatic change that has occurred since the early 1900s until now regarding phosphate, calcium and magnesium has been a reduction in magnesium intake, going from around $500 \mathrm{mg} /$ day to an average of $250 \mathrm{mg} /$ day. Thus, the calcium:magnesium ratio has increased from approximately 2:1 to 5:1, and the phosphate:magnesium ratio has increased from 1.2:1 to around 7:1. ${ }^{60}$ The increase in dietary phosphate has come from phosphate additives, found in many food items but especially processed meats, as well as from phosphoric acid found in soft drinks.

One group of authors concluded: 'The prevalence and incidence of type 2 diabetes in the United States increased sharply between 1994 and 2001 as the ratio of calcium-to-magnesium intake from food rose from $<3.0$ to $>3.0^{\prime} \cdot{ }^{19}$ Another group of authors noted a 3.25fold increased risk of diabetes at plasma magnesium levels $<0.863 \mathrm{mmol} / \mathrm{L}$ (despite $0.75 \mathrm{mmol} / \mathrm{L}$ being considered a 'normal' level). ${ }^{17}$ In other words, patients with diabetes appear to be magnesium-deficient and magnesium deficiency likely increases the risk of diabetes.

Dietary aluminium may lead to magnesium deficit by reducing the absorption of magnesium by approximately fivefold, reducing magnesium retention by $41 \%$ and causing a reduction of magnesium in the bone. ${ }^{68}$ And since aluminium is widely prevalent in modern-day society (such as in aluminium cookware, deodorants, over-the-counter and prescription medications, baking powder, baked goods, and others), this could be a major contributor to magnesium deficiency. In fact, an area near a Skawina aluminium plant in Poland was found to have a lower percentage of people with normal magnesium levels in red blood cells and urine compared with those in Chorzów. ${ }^{69}$
A common misconception is that consuming phytaterich foods can lead to nutrient deficiencies particularly magnesium depletion via binding by phytic acid. However, urinary magnesium excretion will drop to compensate for a reduction in bioavailable magnesium. ${ }^{70}$ And most high-phytate foods are also good sources of magnesium (grains and beans are good examples). Thus, it is unlikely that consuming foods high in phytate will lead to magnesium depletion. However, a vitamin $\mathrm{B}_{6}$-deficient diet can lead to a negative magnesium balance via increased magnesium excretion. ${ }^{71}$

\section{MAGNESIUM BALANCE}

A study of 11 postmenopausal women (aged 49-71 years) found that an intake of $107 \mathrm{mg}$ /day of magnesium was inadequate for maintaining positive magnesium balance. $^{72}$ A placebo-controlled trial in young women who were supplemented with $100 \mathrm{mg}$ magnesium per day (basal magnesium intake $250 \mathrm{mg}$ ) was inadequate for positive or even zero magnesium balance even though the supplemented women had a higher magnesium excretion in urine, indicating a higher total absorption. ${ }^{5}$ In other words, young women may be in negative magnesium balance despite consuming $350 \mathrm{mg}$ of magnesium per day. However, one double-blind metabolic balance study in postmenopausal Caucasian women showed that $318 \mathrm{mg}$ of magnesium per day was enough to remain in positive balance, but $118 \mathrm{mg}$ /day was inadequate. ${ }^{73} \mathrm{~A}$ more recent balance study in postmenopausal women found that while a diet containing $399 \mathrm{mg}$ of magnesium per $2000 \mathrm{kcal}$ was able to produce a positive magnesium balance, a diet containing $\sim 100 \mathrm{mg}$ of magnesium per $2000 \mathrm{kcal}$ was inadequate. ${ }^{74}$ Other data have found negative magnesium balance in men with osteoporosis or psychoneurosis consuming $240 \mathrm{mg}$ /day of magnesium. ${ }^{75}$ Another study noted negative magnesium balance $(-122 \mathrm{mg})$ in those consuming $322 \mathrm{mg} /$ day of magnesium on top of a high-fibre diet. ${ }^{76}$ In other words, context matters (overall dietary pattern, patient population and background medication).

One of the most comprehensive reviews in the literature on this subject suggests that in healthy adults only around $180 \mathrm{mg}$ of magnesium per day is required to maintain balance in healthy individuals (even when taking into account magnesium sweat losses). This analysis pooled magnesium data from 27 different tightly controlled balance studies (lasting more than 27 days) conducted in the USA. ${ }^{77}$ However, it must be noted that this analysis does not take into account the numerous disease states, medications, stress and dietary factors that increase magnesium requirements.

Based on the National Health and Nutrition Examination Survey (NHANES) data, $64 \%$ of women aged $51-70$ years old do not achieve the EAR for this age group $(265 \mathrm{mg} /$ day $),{ }^{77}$ with an estimated average magnesium intake of just $246 \mathrm{mg} /$ day (NHANES 2001-2002) and only $238 \mathrm{mg}$ /day (NHANES 1999-2000). Magnesium 


\begin{tabular}{ll}
\hline $\begin{array}{l}\text { Table 1 Magnesium requirements based on older balance } \\
\text { studies }^{37}\end{array}$ & Requirement \\
\hline Age & $150-200 \mathrm{mg} / \mathrm{day}$ \\
\hline Infants & $200-250 \mathrm{mg} /$ day \\
Children & $250-300 \mathrm{mg} /$ day \\
Adults & $400 \mathrm{mg} /$ day \\
\hline Lactating women
\end{tabular}

intake for Mexican and African-American women of the same age group is even lower $(185 \mathrm{mg} /$ day and $169 \mathrm{mg}$ / day, respectively, and $176 \mathrm{mg} /$ day and $150 \mathrm{mg} /$ day in those reporting no dietary supplement use). ${ }^{77}$ Thus, the elderly population is especially at risk of magnesium deficiency due to low intake but also increased risk for chronic diseases that predispose to magnesium deficiency (ageing also reduces magnesium absorption from the diet, ie, achlorhydria). Table 1 covers the magnesium requirements from older balance studies.

\section{CAUSES OF MAGNESIUM DEFICIENCY}

Numerous factors can lead to magnesium deficiency, such as kidney failure, ${ }^{78}$ alcohol consumption ${ }^{79}$ and malabsorption issues (magnesium is absorbed in the small intestine and in the colon ${ }^{3}$; thus, patients with intestinal or colon damage such as Crohn's disease, irritable bowel syndrome, coeliac disease, gastroenteritis, idiopathic steatorrhoea, ulcerative colitis, resection of the small intestine, ileostomy patients or patients with ulcerative colitis may have magnesium deficiency). Renal tubular acidosis, diabetic acidosis, prolonged diuresis, acute pancreatitis, hyperparathyroidism and primary aldosteronism can also lead to magnesium deficiency. ${ }^{80} \mathrm{~A}$ meta-analysis of 13 studies in almost 5500 patients found that magnesium levels were significantly lower in patients with metabolic syndrome versus controls. ${ }^{81}$ The intravenous magnesium tolerance test has confirmed that children with type 1 diabetes have intracellular magnesium deficiency. ${ }^{82}$ This is likely due to osmotic diuresis and increased magnesuria caused by high glucose levels and damage to the renal tubules. Patients with type 2 diabetes have been found with lower magnesium levels compared with healthy controls $(0.79 \mathrm{mmol} / \mathrm{L}$ vs $0.88 \mathrm{mmol} / \mathrm{L}){ }^{83}$

Supplementing with calcium can lead to magnesium deficiency due to competitive inhibition for absorption, ${ }^{84}$ and oversupplementing with vitamin $\mathrm{D}$ may lead to magnesium deficiency via excessive calcium absorption and hence increase the risk of arterial calcifications. ${ }^{85}$ Use of diuretics and other medications can also lead to magnesium deficiency.

Over $42 \%$ of young (aged 15-18 years) sportsmen (volleyball players and rowers) are magnesium-deficient based on a high retention after an oral magnesium load. The authors of the study concluded '...the magnesium load test a more sensitive indicator of latent Mg deficiency than the serum $\mathrm{Mg}$ level which is maintained at
Box 1 Renal magnesium wasting

- Diagnosis: urinary magnesium excretion $>24 \mathrm{mg} /$ day in the presence of hypomagnesaemia $(<0.7 \mathrm{mmol} / \mathrm{L}) .{ }^{145}$

- Causes

- Bartter's syndrome.

- Gitelman's syndrome.

- Diabetes.

- Hypercalcaemia.

- Diuretics.

- Cisplatinum.

- Aminoglycosides.

- Pentamide.

- Ciclosporin.

- Calcitriol deficiency.

a relatively stable level and declines only in severe deficiency'. ${ }^{86}$ Another study concluded '....athletes suffer from a magnesium deficiency, partially due to physical exercise'. ${ }^{87}$ At a minimum, approximately $15 \mathrm{mg}$ of magnesium is lost in sweat per day, but losses are probably greater especially in conditions of increased perspiration (exercise, heat and humidity) ${ }^{88}$ Box 1 covers renal magnesium wasting. Box 2 provides a comprehensive list of potential causes of magnesium deficiency.

\section{CLINICAL SIGNS OF MAGNESIUM DEFICIENCY}

'...magnesium is essential for the normal metabolism of potassium and of calcium...the occurrence in clinical situations of otherwise unexplained hypokalemia and hypocalcemia should suggest the possibility of significant magnesium depletion' ${ }^{89}$

Among the most common laboratory signs of magnesium deficiency are low potassium and calcium levels, as well as low urine and/or faecal magnesium. The most common neurological side effect with magnesium depletion is the Trousseau sign; that is, 'To elicit the sign, a blood pressure cuff is placed around the arm and inflated to a pressure greater than the systolic blood pressure and held in place for $3 \mathrm{~min}$. This will occlude the brachial artery. In the absence of blood flow, the patient's hypocalcemia and subsequent neuromuscular irritability will induce spasm of the muscles of the hand and forearm. The wrist and metacarpophalangeal joints flex, the DIP and PIP joints extend, and the fingers adduct'. ${ }^{90}$ Other signs of magnesium deficiency included tremor, fasciculations ('a brief spontaneous contraction that affects a small number of muscle fibres. ${ }^{91}$ ), spontaneous carpopedal spasm (painful cramps of the muscles in your hands and feet) and generalised spasticity. ${ }^{89}$ Other clinical features of magnesium deficiency include mental disturbances such as depression, confusion, agitation, hallucinations, weakness, neuromuscular irritability (tremor), athetoid movements and convulsive seizures. ${ }^{80}$

A full list of potential clinical and lab signs of magnesium deficiency are summarised in box 3 and box 4 . 


\section{Box 2 Causes of magnesium deficiency}

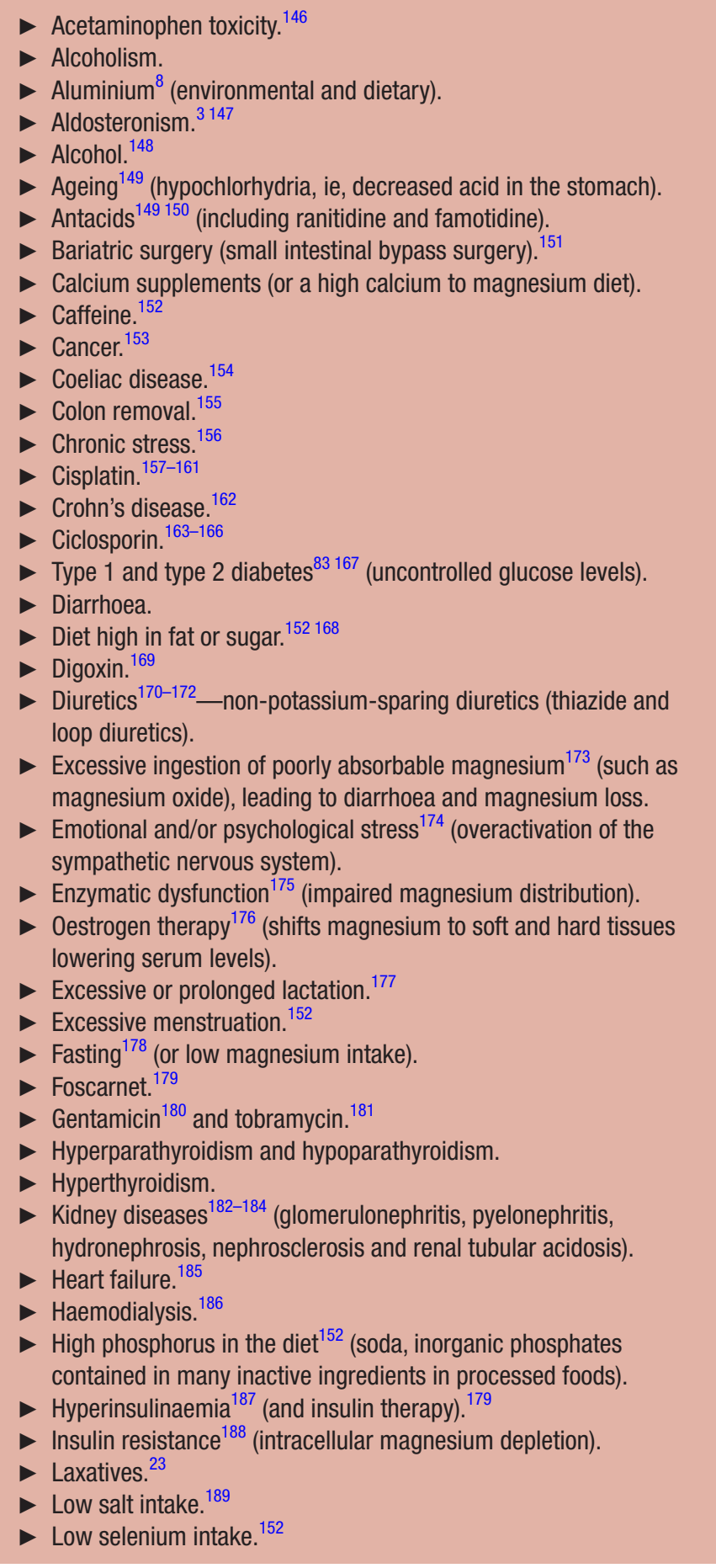

Continued

\section{DIAGNOSING MAGNESIUM DEFICIENCY}

'The existence of subacute or chronic magnesium deficiency is difficult to diagnose. Because the tissues damaged by magnesium depletion are those of the cardiovascular, renal and the neuromuscular systems, early damage is not readily detectable. It is postulated that long-term suboptimal intakes of magnesium may participate in the pathogenesis of chronic diseases of these systems'. ${ }^{88}$

\section{Box 2 Continued}

- Gastrointestinal disorders ${ }^{190}$ —malabsorption syndromes (coeliac disease, non-tropical sprue, bowel resection, Crohn's disease, ulcerative colitis, steatorrhoea), prolonged diarrhoea or vomiting.

- Liver disease ${ }^{191}$ (acute or chronic liver disease, including cirrhosis).

- Metabolic acidosis ${ }^{167192193}$ (latent or clinical).

- Pancreatitis ${ }^{194-197}$ (acute and chronic).

- Parathyroidectomy.

- Pentamide. $^{179}$

- Peritoneal dialysis. ${ }^{198}$

- Porphyria with inappropriate secretion of antidiuretic hormone.

- Pregnancy.

- Proton pump inhibitors. ${ }^{199} 200$

- Strenuous exercise..$^{201}$

- Tacrolimus. $^{179}$

- Vitamin $\mathrm{B}_{6}$ (pyridoxine) deficiency. ${ }^{71} 202$

- Vitamin D excess or deficiency ${ }^{85152184203}$ (chronic kidney disease and liver disease can prevent the activation of vitamin D).

Magnesium deficiency is extremely hard to diagnose since symptoms are generally non-specific, there are numerous contributing factors, and there is no simple easy way to diagnose magnesium deficiency. ${ }^{29}{ }^{80}$ However, one study concluded: 'There is Mg deficiency in many patients with variant angina and it is corrected after treatment with calcium antagonists ${ }^{92}$ The authors noted that the mean 24-hour magnesium retention of an intravenous magnesium load was $60 \%$ in those with variant angina versus $36 \%$ in controls despite both groups having the same normal serum magnesium levels $(2.1 \mathrm{mg} / \mathrm{dL})$.

Gastrointestinal loss of magnesium can be determined by increased renal conservations of magnesium measured by a fractional magnesium excretion of less than $2 \% .^{93}$ Renal magnesium wasting can be determined by a fractional magnesium excretion above $2 \%$ in patients with normal renal function.

\section{Thoren's intravenous magnesium load test (16 hours)}

Thoren has suggested that if less than $70 \%$ of a $30 \mathrm{mEq}$ $(\sim 365 \mathrm{mg})$ to $40 \mathrm{mEq}(\sim 486 \mathrm{mg})$ of parenteral magnesium given over an hour to an adult is excreted in the following 16 hours, this may indicate magnesium deficiency. In other words if you give $\sim 400 \mathrm{mg}$ of magnesium intravenously over 1 hour, if $70 \%$ or more of that dose (so $280 \mathrm{mg}$ or more) is not excreted in the urine over the next 16 hours, this likely indicates magnesium deficiency even in the presence of normal magnesium levels. ${ }^{37}$ An important flaw of this test is in patients who have renal damage who are spilling magnesium out in the urine who could appear magnesium-replete but in actuality could be magnesium-deficient (in this instance the magnesium in the serum would likely be low or low-normal).

\section{Thoren's intravenous magnesium load test for diagnosing magnesium deficiency}

1. Provide $\sim 360-480 \mathrm{mg}$ of magnesium intravenously over 1 hour 
Box 3 Potential clinical signs of magnesium deficiency

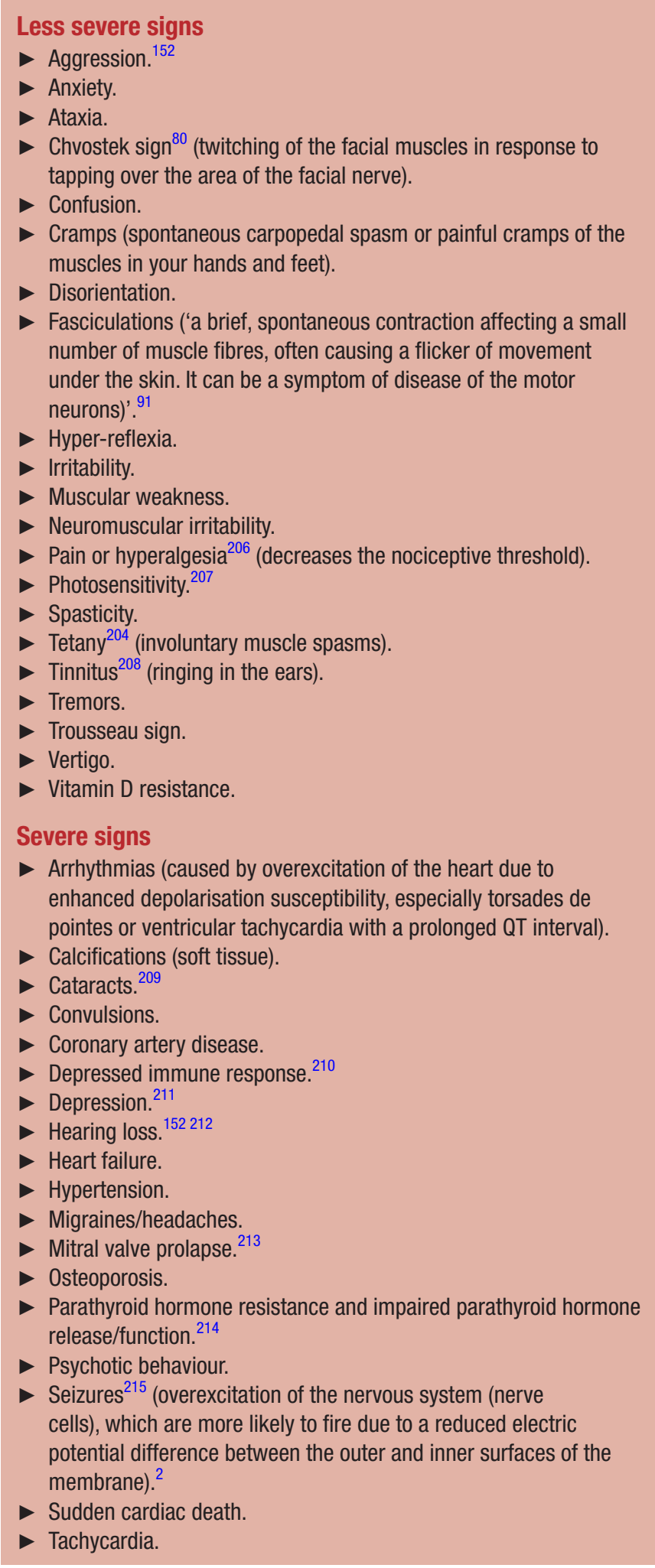

2. If $<70 \%$ of the magnesium load comes out in the urine over 16 hours, this is highly suggestive of magnesium deficiency.

Healthy subjects have been noted to have an intravenous magnesium load retention between $2 \%$ and
Box 4 Lab and ECG signs of magnesium deficiency

- Hypomagnesaemia

- Hypocalcaemia.

- Hypokalaemia.

- Prolonged QTC.

- ST segment depression ${ }^{115}$ (in animals).

$8 \% .{ }^{47}$ Corroborating these findings are another study that found an average magnesium retention from an intravenous load to be $6.3 \%$ in healthy patients aged 18-66 years old. ${ }^{94}$ The $97.5 \%$ fractile was retention of $27.5 \%$. A large percentage of patients who are considered healthy can be magnesium-deficient. Based on these results an intravenous magnesium load retention above $27.5 \%$ is highly suggestive of magnesium deficiency. In fact, one study in healthy patients found a 6\% 24-hour magnesium retention after an intravenous magnesium load in young controls but a $28 \%$ retention in the elderly, suggesting that a large percentage of the elderly population is magnesium-deficient. ${ }^{95}$ The authors of the study concluded: 'This study suggests that a significant subclinical magnesium deficit, not detected by serum magnesium, was present in many of these healthy elderly subjects. Magnesium supplementation improved magnesium status and renal function'.95 If using $2 \mathrm{SD}$ above the mean intravenous magnesium retention in normal younger healthy patients, an abnormally high magnesium retention would be approximately $28 \%$. This suggests that about half of all elderly patients may be magnesium-deficient (a level very close to the $27.5 \%$ retention level found as the upper bound in healthy patients aged $18-66$ years).$^{94}$

The intravenous magnesium load test has been given as $0.2 \mathrm{mmol} / \mathrm{kg} \mathrm{MgSO}_{4}$ over 4 hours $^{96}$ (or around $340 \mathrm{mg}$ of magnesium for a $70 \mathrm{~kg}$ person). One procedure has given magnesium sulfate $\mathrm{MgSO}_{4}(0.2 \mathrm{mmol} / \mathrm{kg}$ body weight) in 250 mL of 5\% dextrose in water at 09:00 over 4 hours. Twenty-four-hour urine samples were then collected starting from the initiation of the infusion to determine 24-hour urinary magnesium excretion. Baseline 24-hour urinary magnesium excretion was then subtracted from postinfusion 24-hour urinary magnesium excretion. The magnesium retention was then calculated by the total amount of magnesium infused - (postinfusion 24-hour urinary magnesium - baseline 24-hour urinary magnesium) $\times 100 /$ total amount of magnesium infused. ${ }^{96}$ Box 5 provides measurements to diagnose magnesium deficiency from best to worst. Box 6 provides a summary of causes of hypermagnesaemia. Box 7 covers treatments for hypermagnesaemia.

\section{TREATMENT OF MAGNESIUM DEFICIENCY}

One group of authors concluded: 'When magnesium substitution is started, the minimum dose to be applied is $600 \mathrm{mg}$ magnesium per day. The therapy should proceed 
Box 5 Measurements to diagnose magnesium deficiency (best to worst)

Reliable methods

- Retention of magnesium load (intravenous or oral) after its administration ${ }^{80} 216$ is likely the best indicator of magnesium deficiency. However, the retention test assumes normal kidney function for intravenous magnesium loads and normal gastrointestinal and renal function for oral load tests and is cumbersome and invasive.

- Mononuclear cell magnesium ${ }^{217} 218$ and muscle magnesium content ${ }^{219}$ (muscle biopsy).

\section{Less reliable methods}

- Hair magnesium content ${ }^{220}{ }^{221}$ (one study concluded: 'magnesium hair concentration may be an easier, cheaper and less invasive indicator of body magnesium depletion'). ${ }^{20}$

- Bone magnesium (magnesium depletion in the coccyx may indicate magnesium deficiency). ${ }^{823}$

- Ratio of ionised magnesium to total magnesium ${ }^{222}$ (serum or plasma).

- Ionised magnesium levels ${ }^{223224}$ (serum or erythrocytes, ionised magnesium is the physiologically active magnesium not bound to proteins). However, this biomarker is controversial and not always available in clinical labs and hard to measure reliably.

- Lymphocyte magnesium. ${ }^{225}$

- Urinary or faecal magnesium excretion ${ }^{89}$ (low or high levels may indicate deficiency).

- Urinary fractional magnesium excretion $>4 \%{ }^{226}$ (some authors have suggested $>2 \%$ in those with normal kidney function). ${ }^{93}$

- Total erythrocyte magnesium levels ${ }^{227}$ (magnesium deficiency has been suggested when erythrocyte magnesium levels are $<1.65 \mathrm{mmol} / \mathrm{L})^{13}$

- Total serum magnesium levels.

- It is important to note that choosing only one of the aforementioned methods of measuring magnesium deficiency is not appropriate for diagnosing magnesium deficiency. In general, either symptoms of magnesium deficiency must accompany the more reliable methods to diagnose magnesium deficiency (eg, intravenous/oral magnesium load, mononuclear cell or muscle), or two or more of the reliable measurements (eg, intravenous/oral magnesium load, mononuclear cell or muscle) should be used in supporting a diagnosis of magnesium deficiency.

for more than one month, and then continue with a dose that holds the serum value not lower than $0.9 \mathrm{mmol} / \mathrm{L}$ magnesium'. ${ }^{36}$ The authors noted that using a cut-off of $0.75 \mathrm{mmol} / \mathrm{L}$ for magnesium deficiency misses $50 \%$ of those with true magnesium deficiency.

\section{Box 6 Causes of hypermagnesaemia}

Oversupplementation (mainly from magnesium containing antacids). ${ }^{228}$

Kidney damage. ${ }^{229}$

- Inflammation and cellular injury ${ }^{230}$ (significant increases in total and ionised magnesium in animals during endotoxin challenge).

\section{Box 7 Treatment of hypermagnesaemia}

Diuresis or dialysis ${ }^{231}$ (to increase renal elimination of magnesium).

Supportive care.

\section{CONSEQUENCES OF MAGNESIUM DEFICIENCY Hypertension}

'Magnesium status has a direct effect upon the relaxation capability of vascular smooth muscle cells and the regulation of the cellular placement of other cations important to blood pressure - cellular sodium:potassium (Na:K) ratio and intracellular calcium (iCa(2+)). As a result, nutritional magnesium has both direct and indirect impacts on the regulation of blood pressure and therefore on the occurrence of hypertension'. ${ }^{97}$

It must be remembered that there is magnesiumATP-driven sodium-potassium pump and calcium pump. ${ }^{97}$ Magnesium deficiency leads to dysfunction of the Na-K-ATPase depleting intracellular $\mathrm{K}$ and increasing intracellular sodium and calcium in cardiac and smooth muscle cells. This can cause vasoconstriction of venous smooth muscles and arteries causing hypertension. ${ }^{3}$ Magnesium deficiency may also predispose to an increased response to vasoconstrictors, such as angiotensin II and catecholamines. ${ }^{98}$

Many patients with hypertension are treated with thiazide and loop diuretics, both of which deplete the body of magnesium, ${ }^{99}$ and giving patients with hypertension who are receiving long-term thiazide diuretics oral magnesium supplementation significantly reduces blood pressure. ${ }^{99}$ In fact, the high intracellular calcium induced by magnesium deficiency may induce both insulin resistance and hypertension. ${ }^{100} \mathrm{~A}$ meta-analysis of randomised, doubleblind, placebo-controlled trials in normotensive and hypertensive adults found that $368 \mathrm{mg}$ / day of magnesium for a median of 3 months significantly reduces systolic blood pressure by $2.00 \mathrm{~mm} \mathrm{Hg}$ and diastolic blood pressure by $1.78 \mathrm{~mm} \mathrm{Hg.}{ }^{101}$ In fact, a meta-analysis of seven studies encompassing 135 patients with hypertension on antihypertensive medications with a mean starting blood pressure $>155 \mathrm{~mm} \mathrm{Hg}$ found that magnesium supplementation reduced blood pressure by $-18.7 /-10.9 \mathrm{~mm} \mathrm{Hg} .{ }^{102}$ Another meta-analysis of 22 trials using a mean dose of $410 \mathrm{mg}$ of magnesium found a significant reduction in systolic (3-4 mm $\mathrm{Hg}$ ) and diastolic (2-3 mm Hg) blood pressure. The effect on blood pressure was greater when magnesium doses $>370 \mathrm{mg} /$ day were used.

Low magnesium levels can promote endothelial cell dysfunction, potentially increasing the risk of thrombosis and atherosclerosis. ${ }^{103}$ Magnesium deficiency also promotes a proatherogenic phenotype in endothelial cells. ${ }^{104}$ Hypomagnesaemia can impair the release of nitric oxide from the coronary endothelium, ${ }^{105}$ while magnesium therapy can improve endothelium-dependent vasodilation in patients with coronary artery disease. ${ }^{105}$ Since nitric oxide is both a vasodilator and an 
inhibitor of platelet aggregation, this makes magnesium supplementation a promising therapy in the treatment of hypertension and coronary artery disease. Indeed, magnesium therapy may enhance prostacyclin release from the vascular wall. ${ }^{106}$

\section{Atherosclerosis and calcifications}

Magnesium deficiency and magnesium depletion in soft tissues can cause calcifications in the heart, liver and skeletal muscles. ${ }^{107}$ Magnesium deficiency may be a leading cause of kidney disease as it leads to swelling of the tubular epithelium, apatite crystal deposition in the proximal convoluted tubules, loops of Henle, collecting tubules and in the pars recta. ${ }^{108}$ Thus, magnesium deficiency damages the kidneys due to calcium deposits and may cause numerous electrolyte abnormalities (a common problem in patients with chronic kidney disease). Other studies in animals show that magnesium deficiency causes cardiac necrosis and calcifications. ${ }^{109}$ Magnesium deficiency can calcify the descending limb of the loop of Henle, which may lead to dehydration and volume depletion by reducing water reabsorption. ${ }^{108} \mathrm{~A}$ greater intake of magnesium is associated with having a lower risk of an elevated coronary artery calcification score, ${ }^{110}$ and supplementing with magnesium has been found to improve endothelial function in patients with coronary artery disease. ${ }^{111}$

One animal study noted: '.. the degree of lipid deposition in the aorta of cholesterol-fed rabbits can be significantly enhanced by feeding a magnesium-deficient diet... The calcification of the inflammatory granuloma of the aortas and the atrophy and degeneration of muscle fibres with inflammatory connective tissue proliferation in the myocardium and in the stomach and skeletal muscles were only observed in rabbits fed a magnesium deficient diet'. ${ }^{112}$ In other words, eating a diet deficient in magnesium predisposes to atherosclerosis, calcification of the aorta, degeneration of myocardial muscle fibres and inflammatory connective tissue throughout the body. This study suggests that low magnesium intake increases inflammation.

Inadequate dietary magnesium intake increases atherosclerotic plaque development in rabbits ${ }^{113}$ and induces myocardial fibrosis similar to what is found in human cardiomyopathy endomyocardial fibrosis. ${ }^{114} \mathrm{~A}$ diet deficient in magnesium in the Cebus monkey causes an increase in serum cholesterol, ST segment depression and atherosclerotic plaques in the aorta, ${ }^{115}$ whereas magnesium fortification in drinking water inhibits atherogenesis in female and male Low-density lipoprotein (LDL)-receptor-deficient mice fed a high-cholesterol diet. ${ }^{116117}$

Magnesium treatment for 3 months in patients with ischaemic heart disease increases the apolipoprotein A1:apolipoprotein B ratio by $13 \%$, decreases the apolipoprotein $\mathrm{B}$ concentrations by $15 \%$, and decreases verylow-density lipoprotein concentrations by $27 \% .{ }^{118}$ Magnesium therapy also tended to increase high-density lipoprotein. The authors of the study concluded: '...magnesium deficiency might be involved in the pathogenesis of ischemic heart disease by altering the blood lipid composition in a way that disposes to atherosclerosis'. ${ }^{118}$ In hypomagnesaemic kidney transplant recipients, magnesium supplementation significantly decreases total cholesterol, low-density lipoprotein and total cholesterol:high density lipoprotein ratio. ${ }^{119}$ Magnesium deficiency may enhance vascular endothelial injury, promoting the development and progression of atherosclerosis. ${ }^{120}$

Magnesium deficiency may supersaturate bodily fluids with octacalcium phosphate calcifying soft tissues, whereas magnesium therapy may stop or even prevent soft tissue calcifications. ${ }^{121}$ Magnesium deficiency in Yorkshire swine induces numerous calcifications and smooth muscle cell degeneration, and promotes atherosclerosis in combination with an atherogenic diet. ${ }^{122}$ Hamsters fed a magnesium-deficient diet develop myocardial necrosis, calcifications and cardiomyopathy. These effects of magnesium deficiency seem to be secondary to the inhibition of the Na-K-ATPase and the calcium overload that follows in cardiac myocytes. ${ }^{123}$ Triglyceride-rich lipoproteins from magnesium-deficient rats are more susceptible to oxidation. ${ }^{124}$ Thus, magnesium deficiency predisposes to lipoprotein peroxidation and atherosclerosis. Perhaps most importantly, patients in the intensive cardiac care unit have been noted to have low blood mononuclear cell magnesium levels. ${ }^{125}$ The authors summarised their findings as the following: 'We conclude that the incidence of intracellular Mg deficiency in patients with cardiovascular disease is much higher than the serum magnesium would lead one to suspect, and may contribute to clinical cardiovascular morbidity'. ${ }^{125}$

\section{Arrhythmias}

'Although available on order by physicians, the lack of routine serum $\mathrm{Mg}$ analysis as part of the 'electrolyte panel' impedes the diagnosis of clinical $\mathrm{Mg}$ deficiency. Renal loss of $\mathrm{Mg}$ resulting from the widespread use of loop diuretics is responsible for significant numbers of patients with $\mathrm{Mg}$ deficiency and hypomagnesemia. Life-threatening cardiac arrhythmias and seizures represent the most serious manifestation of clinical hypomagnesemia and $\mathrm{Mg}$ depletion [...] Hypomagnesemia is one of the most frequent serum electrolyte abnormalities in current clinical practice. Routine inclusion of serum $\mathrm{Mg}$ analysis in the electrolyte panel will enhance the clinical recognition and treatment of hypomagnesemic Mg-depleted patients. Failure to respond to treatment of recurrent ventricular tachycardia/fibrillation to usual antiarrhythmic therapy in patients with acute myocardial infarction, idiopathic dilated cardiomyopathy, and congestive heart failure should alert the clinician to consider administering intravenous $\mathrm{Mg} .{ }^{2}{ }^{26}$

As noted previously, magnesium deficiency reduces cardiac Na-K-ATPase, leading to higher levels of sodium and calcium and lower levels of magnesium and potassium in the heart. This increases vasoconstriction in the coronary arteries, which can induce coronary artery spasms, 
myocardial infarction and arrhythmias. ${ }^{127}$ Considering that around $25 \%$ of all myocardial infarctions are not due to atherosclerotic plaque rupture, coronary artery spasm induced by magnesium deficiency may explain some of these events.

In one metabolic study of 22 postmenopausal women, a low-magnesium diet (containing around $130 \mathrm{mg}$ / day) significantly increased both supraventricular and supraventricular plus ventricular beats based on Holter monitor. The authors of the study concluded: 'The recommended dietary allowance of $320 \mathrm{mg} /$ day seems correct; $130 \mathrm{mg}$ is too little. Persons who live in soft water areas, who use diuretics, or who are predisposed to magnesium loss or ectopic beats may require more dietary magnesium than would others'. ${ }^{128}$ Another study in postmenopausal women found that a low-magnesium diet (approximately $100 \mathrm{mg}$ /day) can induce atrial fibrillation and increases glucose levels. ${ }^{129}$ Patients with diabetes mellitus and arrhythmia have been noted to have lower serum levels of ionised magnesium. ${ }^{130}$ Thus, it appears that low dietary intake of magnesium or low magnesium levels can predispose to arrhythmias. Diuretics and digoxin also cause magnesium depletion, making the heart more susceptible to the development of arrhythmias. ${ }^{131}$

Hypomagnesaemia may induce arrhythmias including torsades de pointes ventricular tachycardia. ${ }^{132}$ Magnesium therapy may be useful in the treatment of refractory ventricular tachycardia, ventricular fibrillation, multifocal atrial tachycardia, atrial fibrillation and supraventricular tachycardia. ${ }^{133}$ A meta-analysis of 19 randomised trials using magnesium orotate found a significant reduction in first-degree mitral valve prolapse, grade 1 regurgitation, supraventricular and ventricular premature contraction, and paroxysmal supraventricular tachycardia. ${ }^{134}$

\section{Coronary artery disease}

'...low heart muscle magnesium may contribute to sudden death after myocardial infarction. Western diets are probably often low in magnesium, so that the magnesium in hard drinking water may help to protect its consumers from ischemic heart disease...Increasing the magnesium content of the diet may help to prevent ischemic heart disease, and there is already evidence that magnesium salts can have beneficial effects on established heart disease'. ${ }^{131}$

Autopsy studies have revealed lower magnesium content in both infarcted and non-infarcted heart muscle in those who have died of a myocardial infarction. ${ }^{131}$ Furthermore, autopsy studies have noted that those dying from accidents have lower heart muscle magnesium in soft-water drinking areas versus those from hard-water areas. This suggests that patients who have lower than normal magnesium concentrations in their heart muscle may be more likely to die suddenly after a myocardial infarction. Indeed, there are numerous studies indicating an increased rate of death from heart disease in low-magnesium drinking water areas. ${ }^{131}$
Magnesium is required for the formation and activation of ATP and is essential for heart muscle contraction and oxidative phosphorylation in heart mitochondria. ${ }^{131}$ There is also a rapid loss of myocardial magnesium during anoxia, suggesting that chronic angina leads to magnesium deficiency. Chipperfield and Chipperfield ${ }^{131}$ noted: 'Magnesium-deficient diets...predispose animals to the development of myocardial fiber necrosis. Administration of magnesium salts has been shown to reverse many of the changes in animal models of heart disease...There is also good evidence from some animal studies that pretreatment with magnesium salts protects against many of the changes in the heart caused by anoxia...' In other words, consuming a diet high in magnesium may prevent the harms from an acute ischaemic events.

Just 42-64 days on a diet low in magnesium $(\sim 101 \mathrm{mg} /$ day $)$ produced atrial fibrillation and flutter in three of five postmenopausal women (ages 47-75 years). Moreover, the arrhythmias responded quickly to magnesium supplementation. During the low-magnesium diet, glucose levels increased and red blood cell superoxide dismutase decreased. The authors of the study concluded: 'A dietary intake of about $4.12 \mathrm{mmol}$ ( $101 \mathrm{mg} /$ day, my insertion) $\mathrm{Mg} / 8.4 \mathrm{MJ}$ is inadequate for healthy adults and may result in compromised cardiovascular health and glycemic control in postmenopausal women'. ${ }^{129}$

In a randomised, double-blind, placebo controlled study on 350 patients with acute myocardial infarction, intravenous magnesium sulfate given immediately after completion of thrombolytic therapy significantly reduced all-cause mortality $(3.5 \%$ vs $9.9 \%, \mathrm{P}<0.01)$ and ventricular arrhythmias $(13 \%$ vs $48.6 \%, \mathrm{P}=0.00001){ }^{135}$ There was also a numerical reduction in reinfarction ( $8.8 \%$ vs $12.7 \%$, $\mathrm{P}$ value not significant).

Magnesium deficiency in swine leads to proaggregatory and procoagulation alterations, ${ }^{136}$ and in humans leads to increased thromboxane synthesis. ${ }^{137}$ In rats, magnesium deficiency increases thromboxane B2 outflow. ${ }^{138}$ Magnesium treatment has been found to inhibit thrombus formation (as measured by platelet-dependent thrombosis) in patients with stable coronary artery disease by $35 \% .{ }^{105}$ These effects are additive to that of aspirin and are independent of platelet aggregation. One author concluded: 'High dose of intravenous magnesium can inhibit thrombus formation and is associated with suppression of platelet aggregation. Magnesium treatment can dose-dependently inhibit a wide variety of agonists of platelet aggregation, such as thromboxane A2 and stimulate prostacyclin synthesis. The molecular basis for these effects is likely modulated via reduction of intracellular calcium mobilization' ${ }^{105}$ Thus, magnesium may prevent thrombotic events and may also protect cardiac cells against ischaemia. ${ }^{139}$

Platelet-dependent thrombosis is significantly higher in patients with stable coronary artery disease with low intracellular magnesium levels. ${ }^{140}$ Administration of 
Box 8 Possible cardiovascular manifestations of magnesium deficiency

- Hypertension.

- Arrhythmias.

- Calcifications.

- Atherosclerosis.

- Heart failure.

- Increased platelet reactivity and thrombosis

- Myocardial infarction.

- Stroke.

Sudden cardiac death.

intravenous magnesium to healthy volunteers significantly inhibits both ADP-induced platelet aggregation by $40 \%$ and binding of fibrinogen or surface expression of GMP-140 by 30\%. ${ }^{141}$ Thus, magnesium therapy also has antiplatelet effects. In rats, intravenous magnesium therapy inhibits arterial thrombi after vascular injury. ${ }^{142}$ All of these suggest that magnesium is an antithrombotic and antiplatelet agent and that magnesium deficiency may promote thrombosis. Furthermore, magnesium deficiency appears to be more prevalent in patients with coronary artery disease or ischaemic heart disease, suggesting a need for magnesium treatment. ${ }^{143} 144$ Box 8 provides a summary of possible cardiovascular manifestations of magnesium deficiency.

\section{CONCLUSION}

Subclinical magnesium deficiency is a common and under-recognised problem throughout the world. Importantly, subclinical magnesium deficiency does not manifest as clinically apparent symptoms and thus is not easily recognised by the clinician. Despite this fact, subclinical magnesium deficiency likely leads to hypertension, arrhythmias, arterial calcifications, atherosclerosis, heart failure and an increased risk for thrombosis. This suggests that subclinical magnesium deficiency is a principal, yet under-recognised, driver of cardiovascular disease. A greater public health effort is needed to inform both the patient and clinician about the prevalence, harms and diagnosis of subclinical magnesium deficiency.

Contributors JJD performed the literature search and wrote the manuscript. JHO and WW edited the final manuscript.

Competing interests JJD is the author of The Salt Fix and operates the website the saltfix.com.

Provenance and peer review Not commissioned; externally peer reviewed.

Data sharing statement There are no additional data available for this paper.

Open Access This is an Open Access article distributed in accordance with the Creative Commons Attribution Non Commercial (CC BY-NC 4.0) license, which permits others to distribute, remix, adapt, build upon this work non-commercially, and license their derivative works on different terms, provided the original work is properly cited and the use is non-commercial. See: http://creativecommons.org/ licenses/by-nc/4.0/

(c) Article author(s) (or their employer(s) unless otherwise stated in the text of the article) 2018. All rights reserved. No commercial use is permitted unless otherwise expressly granted.

\section{REFERENCES}

1. Kielstein JT, David S. Magnesium: the 'earth cure' of AKI? Nephrol Dial Transplant 2013;28:785-7.

2. Canelas HM, De Assis LM, De Jorge FB. Disorders of magnesium metabolism in epilepsy. J Neurol Neurosurg Psychiatry 1965;28:378-81.

3. Wacker WE, Parisi AF. Magnesium metabolism. N Engl J Med 1968;278:658-63.

4. Martyka Z, Kotela I, Blady-Kotela A. [Clinical use of magnesium]. Przegl Lek 1996;53:155-8.

5. Vormann J. Magnesium: nutrition and metabolism. Mol Aspects Med 2003;24:27-37.

6. Abbott LG, Rude RK. Clinical manifestations of magnesium deficiency. Miner Electrolyte Metab 1993;19:314-22.

7. Rude RK, Gruber HE. Magnesium deficiency and osteoporosis: animal and human observations. J Nutr Biochem 2004;15:710-6.

8. Smith RH. Calcium and magnesium metabolism in calves. 4. Bone composition in magnesium deficiency and the control of plasma magnesium. Biochem J 1959;71:609-14.

9. Yasui M, Yase Y, Ota K, et al. calcium and aluminum deposition in bone in situ]. No To Shinkei 1991;43:577-82.

10. Ubom GA. The goitre-soil-water-diet relationship: case study in Plateau State, Nigeria. Sci Total Environ 1991;107:1-11.

11. Louzada ML, Martins AP, Canella DS, et al. Impact of ultraprocessed foods on micronutrient content in the Brazilian diet. Rev Saude Publica 2015;49:1-8.

12. Marier JR. Magnesium content of the food supply in the modernday world. Magnesium 1986;5:1-8.

13. Hermes Sales C, Azevedo Nascimento D, Queiroz Medeiros AC, et al. There is chronic latent magnesium deficiency in apparently healthy university students. Nutr Hosp 2014;30:200-4.

14. Elin RJ. Re-evaluation of the concept of chronic, latent, magnesium deficiency. Magnes Res 2011;24:225-7.

15. Durlach J. Recommended dietary amounts of magnesium: Mg RDA. Magnes Res 1989;2:195-203.

16. Gillis L, Gillis A. Nutrient inadequacy in obese and non-obese youth. Can J Diet Pract Res 2005;66:237-42.

17. Wang JL, Shaw NS, Yeh HY, et al. Magnesium status and association with diabetes in the Taiwanese elderly. Asia Pac J Clin Nutr 2005;14:263-9.

18. Itokawa Y. [Magnesium intake and cardiovascular disease]. Clin Calcium 2005;15:154-9.

19. Rosanoff A, Weaver CM, Rude RK. Suboptimal magnesium status in the United States: are the health consequences underestimated? Nutr Rev 2012;70:153-64.

20. Costello RB, Elin RJ, Rosanoff $A$, et al. Perspective: the case for an evidence-based reference interval for serum magnesium: The time has come. Advances in Nutrition: An International Review Journal 2016;7:977-93.

21. Lakshmanan FL, Rao RB, Kim WW, et al. Magnesium intakes, balances, and blood levels of adults consuming self-selected diets. Am J Clin Nutr 1984;40:1380-9.

22. Tipton IH, Stewart PL, Dickson J. Patterns of elemental excretion in long term balance studies. Health Phys 1969;16:455-62.

23. Vormann J, Anke M. Dietary magnesium: supply, requirements and recommendations-results from duplicate and balance studies in man. J Clin Basic Cardiol 2002;5:49-53.

24. Davydenko NV, Vasilenko IG. [Magnesium level in food rations and the prevalence of ischemic heart disease among the population]. Gig Sanit 1991:44-6.

25. Durlach J. New data on the importance of gestational $\mathrm{Mg}$ deficiency. J Am Coll Nutr 2004;23:694S-700.

26. Carrière I, Delcourt C, Lacroux A, et al. Nutrient intake in an elderly population in southern France (POLANUT): deficiency in some vitamins, minerals and omega-3 PUFA. Int $J$ Vitam Nutr Res 2007;77:57-65.

27. Touvier $\mathrm{M}$, Lioret $\mathrm{S}$, Vanrullen I, et al. Vitamin and mineral inadequacy in the French population: estimation and application for the optimization of food fortification. Int J Vitam Nutr Res 2006;76:343-51.

28. Henzel JH, DeWeese MS, Ridenhour G. Significance of magnesium and zinc metabolism in the surgical patient. I. Magnesium. Arch Surg 1967;95:974-90.

29. Costello RB, Elin RJ, Rosanoff A, et al. Perspective: the case for an evidence-based reference interval for serum magnesium: The time has come. Adv Nutr 2016;7:977-93.

30. Mejía-Rodríguez F, Shamah-Levy T, Villalpando S, et al. Iron, zinc, copper and magnesium deficiencies in Mexican adults from the National Health and Nutrition Survey 2006. Salud Publica Mex 2013;55:275-84. 
31. Guillaume T, Krzesinski JM. [Management of serum magnesium abnormalities]. Rev Med Liege 2003;58:465-7.

32. ter Borg S, Verlaan S, Hemsworth J, et al. Micronutrient intakes and potential inadequacies of community-dwelling older adults: a systematic review. Br J Nutr 2015;113:1195-206.

33. Cohen L, Kitzes R. Infrared spectroscopy and magnesium content of bone mineral in osteoporotic women. Isr J Med Sci $1981 ; 17: 1123-5$

34. Lima ML, Pousada J, Barbosa C, et al. [Magnesium deficiency and insulin resistance in patients with type 2 diabetes mellitus]. Arq Bras Endocrinol Metabol 2005;49:959-63.

35. Touitou Y, Godard JP, Ferment O, et al. Prevalence of magnesium and potassium deficiencies in the elderly. Clin Chem 1987;33:518-23.

36. Liebscher DH, Liebscher DE. About the misdiagnosis of magnesium deficiency. J Am Coll Nutr 2004;23:730S-1.

37. Caddell JL. Magnesium deficiency in man. Del Med $\mathrm{J}$ 1968;40:133-8

38. Dørup I, Skajaa K. [Magnesium and long-term diuretic therapy]. Ugeskr Laeger 1989;151:759-63.

39. Malon A, Brockmann C, Fijalkowska-Morawska J, et al. Ionized magnesium in erythrocytes-the best magnesium parameter to observe hypo- or hypermagnesemia. Clin Chim Acta 2004;349:67-73.

40. Ryzen E. Magnesium homeostasis in critically ill patients. Magnesium 1989;8:201-12.

41. Whang R. Routine serum magnesium determination-a continuing unrecognized need. Magnesium 1987;6:1-4.

42. Schimatschek HF, Rempis R. Prevalence of hypomagnesemia in an unselected German population of 16,000 individuals. Magnes Res 2001;14:283-90.

43. Martin BJ, Black J, McLelland AS. Hypomagnesaemia in elderly hospital admissions: a study of clinical significance. Q J Med 1991;78:177-84

44. Escuela MP, Guerra M, Añón JM, et al. Total and ionized serum magnesium in critically ill patients. Intensive Care Med 2005;31:151-6.

45. Rubeiz GJ, Thill-Baharozian M, Hardie D, et al. Association of hypomagnesemia and mortality in acutely ill medical patients. Crit Care Med 1993;21:203-9.

46. Olerich MA, Rude RK. Should we supplement magnesium in critically ill patients? New Horiz 1994;2:186-92.

47. Gullestad L, Dolva LO, Waage A, et al. Magnesium deficiency diagnosed by an intravenous loading test. Scand J Clin Lab Invest 1992;52:245-53.

48. Ismail Y, Ismail AA, Ismail AA. The underestimated problem of using serum magnesium measurements to exclude magnesium deficiency in adults; a health warning is needed for 'normal' results. Clin Chem Lab Med 2010;48:323-7.

49. Wilhelm Z, Hegyi P, Kleinová J, et al. [Diagnosis of magnesium deficiency in the body, personal experience]. Vnitr Lek 2004;50:291-9.

50. Wälti MK, Zimmermann MB, Spinas GA, et al. Low plasma magnesium in type 2 diabetes. Swiss Med Wkly 2003;133:289-92.

51. Rolla G, Bucca C, Bugiani M, et al. Hypomagnesemia in chronic obstructive lung disease: effect of therapy. Magnes Trace Elem 1990;9:132-6.

52. Whang R, Ryder KW. Frequency of hypomagnesemia and hypermagnesemia. Requested vs routine. JAMA 1990;263:3063-4.

53. Seelig CB. Magnesium deficiency in two hypertensive patient groups. South Med J 1990;83:739-42.

54. Malini PL, Strocchi E, Valtancoli G, et al. Angiotensin converting enzyme inhibitors, thiazide diuretics and magnesium balance. A preliminary study. Magnes Res 1990;3:193-6.

55. Cohen L, Laor A. Correlation between bone magnesium concentration and magnesium retention in the intravenous magnesium load test. Magnes Res 1990;3:271-4.

56. Dolev E, Burstein R, Wishnitzer R, et al. Longitudinal study of magnesium status of Israeli military recruits. Magnes Trace Elem 1991;10:420-6.

57. Buchman AL, Keen C, Commisso J, et al. The effect of a marathon run on plasma and urine mineral and metal concentrations. J Am Coll Nutr 1998;17:124-7.

58. Guérin $\mathrm{C}$, Cousin $\mathrm{C}$, Mignot $\mathrm{F}$, et al. Serum and erythrocyte magnesium in critically ill patients. Intensive Care Med 1996;22:724-7.

59. Spätling L, Classen HG, Külpmann WR, et al. [Diagnosing magnesium deficiency. Current recommendations of the Society for Magnesium Research]. Fortschr Med Orig 2000;118(Suppl 2):49-53.
60. https://books.google.com/books?id=dP_pBwAAQBAJ\&pg=PA460\& $\mathrm{lpg}=\mathrm{PA} 460 \& \mathrm{dq}=$ Thoren, $+\mathrm{L} \# \mathrm{v}=$ onepage \&q=Thoren\%2C\%20L\&f= false.

61. Nutrition and Health. The mineral depletion of foods available to us as a nation (1940-2002) - a review of the 6th edition of mccance and widdowson*. UK: A B Academic Publishers, 2007;19:21-55. http://www.mineralresourcesint.co.uk/pdf/Mineral_Depletion_of_ Foods_1940_2002.pdf

62. Guo W, Nazim H, Liang Z, et al. Magnesium deficiency in plants: an urgent problem. Crop J 2016;4:83-91.

63. O'Dell BL. Magnesium requirement and its relation to other dietary constitunents. Fed Proc 1960;19:648-54.

64. Bunce GE, Sauberlich HE, Reeves PG, et al. Dietary phosphorus and magnesium deficiency in the rat. J Nutr 1965;86:406-13.

65. Bunce GE, Chiemchaisri Y, Phillips PH. The mineral requirements of the dog. IV. Effect of certain dietary and physiologic factors upon the magnesium deficiency syndrome. J Nutr 1962;76:23-9.

66. Self Nutrition Data. Nutrition facts label for Cheese, cheddar. http:// nutritiondata.self.com/facts/dairy-and-egg-products/8/2

67. Self Nutrition Data. Seeds, pumpkin and squash seeds, whole, roasted, without salt. http://nutritiondata.self.com/facts/nut-andseed-products $/ 3141 / 2$

68. Neathery MW, Crowe NA, Miller WJ, et al. Effects of dietary aluminum and phosphorus on magnesium metabolism in dairy calves. J Anim Sci 1990;68:1133-8.

69. Stachurska MB, Gumińska M. [Magnesium in the blood and urine of the population living in polluted environment of Chorzów]. Folia Med Cracov 1991;32:89-94.

70. Brink EJ, Beynen AC. Nutrition and magnesium absorption: a review. Prog Food Nutr Sci 1992;16:125-62.

71. Turnlund JR, Betschart AA, Liebman M, et al. Vitamin B-6 depletion followed by repletion with animal- or plant-source diets and calcium and magnesium metabolism in young women. Am J Clin Nutr 1992;56:905-10.

72. Nielsen FH, Milne DB, Gallagher S, et al. Moderate magnesium deprivation results in calcium retention and altered potassium and phosphorus excretion by postmenopausal women. Magnes Res 2007;20:19-31.

73. Nielsen FH. The alteration of magnesium, calcium and phosphorus metabolism by dietary magnesium deprivation in postmenopausal women is not affected by dietary boron deprivation. Magnes Res 2004; $17: 197-210$.

74. Nielsen FH, Milne DB. Some magnesium status indicators and oxidative metabolism responses to low-dietary magnesium are affected by dietary copper in postmenopausal women. Nutrition 2003:19:617-26.

75. Spencer $\mathrm{H}$, Fuller $\mathrm{H}$, Norris $\mathrm{C}$, et al. Effect of magnesium on the intestinal absorption of calcium in man. J Am Coll Nutr 1994:13:485-92.

76. Kelsay JL, Behall KM, Prather ES. Effect of fiber from fruits and vegetables on metabolic responses of human subjects, II. Calcium, magnesium, iron, and silicon balances. Am J Clin Nutr 1979;32:1876-80.

77. Hunt CD, Johnson LK. Magnesium requirements: new estimations for men and women by cross-sectional statistical analyses of metabolic magnesium balance data. Am J Clin Nutr 2006;84:843-52.

78. Lim P, Dong S, Khoo OT. Intracellular magnesium depletion in chronic renal failure. N Engl J Med 1969;280:981-4.

79. Rylander R, Mégevand Y, Lasserre B, et al. Moderate alcohol consumption and urinary excretion of magnesium and calcium. Scand J Clin Lab Invest 2001:61:401-5.

80. Anon. Magnesium deficiency. Br Med J 1967;2:195.

81. La SA, Lee JY, Kim DH, et al. Low magnesium levels in adults with metabolic syndrome: a meta-analysis. Biol Trace Elem Res 2016;170:33-42.

82. Uğurlu V, Binay C, Simsek E, et al. Cellular trace element changes in type 1 diabetes patients. $J$ Clin Res Pediatr Endocrinol 2016;8:180-6.

83. Schnack C, Bauer I, Pregant P, et al. Hypomagnesaemia in type 2 (non-insulin-dependent) diabetes mellitus is not corrected by improvement of long-term metabolic control. Diabetologia 1992;35:77-9.

84. Booth CC, Babouris N, Hanna S, et al. Incidence of hypomagnesaemia in intestinal malabsorption. $\mathrm{Br} \mathrm{Med} \mathrm{J}$ 1963;2:141-4

85. Richardson JA, Welt LG. The hypomagnesemia of vitamin $d$ administration. Proc Soc Exp Biol Med 1965;118:512-4.

86. Vizinová $\mathrm{H}$, Bártek J, Jirka Z, et al. [The oral magnesium loading test for detecting possible magnesium deficiency]. Cas Lek Cesk 1993:132:587-9. 
87. Casoni I, Guglielmini C, Graziano L, et al. Changes of magnesium concentrations in endurance athletes. Int J Sports Med 1990;11:234-7.

88. Seelig MS. The requirement of magnesium by the normal adult. Summary and analysis of published data. Am J Clin Nutr 1964;14:242-90.

89. Shils ME. Experimental human magnesium depletion. Medicine 1969;48:61-85

90. Wikipedia, The Free Encyclopedia. Trousseau sign of latent tetany. https://en.wikipedia.org/wiki/Trousseau_sign_of_latent_tetany

91. de Carvalho M, Kiernan MC, Swash M. Fasciculation in amyotrophic lateral sclerosis: origin and pathophysiological relevance. J Neurol Neurosurg Psychiatry 2017;88:773-9.

92. Goto K, Yasue H, Okumura K, et al. Magnesium deficiency detected by intravenous loading test in variant angina pectoris. Am J Cardiol 1990;65:709-12.

93. Assadi F. Hypomagnesemia: an evidence-based approach to clinical cases. Iran J Kidney Dis 2010;4:13-19.

94. Gullestad L, Midtvedt K, Dolva LO, et al. The magnesium loading test: reference values in healthy subjects. Scand J Clin Lab Invest 1994;54:23-31.

95. Gullestad L, Nes M, Rønneberg R, et al. Magnesium status in healthy free-living elderly Norwegians. J Am Coll Nutr 1994;13:45-50.

96. Ozono R, Oshima T, Matsuura H, et al. Systemic magnesium deficiency disclosed by magnesium loading test in patients with essential hypertension. Hypertens Res 1995;18:39-42.

97. Rosanoff A. [Magnesium and hypertension]. Clin Calcium 2005;15:255-60

98. Singh RB, Rastogi SS, Mehta PJ, et al. Magnesium metabolism in essential hypertension. Acta Cardiol 1989;44:313-22.

99. Saito K, Hattori K, Omatsu T, et al. Effects of oral magnesium on blood pressure and red cell sodium transport in patients receiving long-term thiazide diuretics for hypertension. Am J Hypertens 1988;1:71S-4.

100. Rayssiguier Y, Rock E. Commentary to the letter to the editor re: role of magnesium in metabolic syndrome. Magnes Res 2010;23:146.

101. Zhang X, Li Y, Del Gobbo LC, et al. Effects of magnesium supplementation on blood pressure: A meta-analysis of randomized double-blind placebo-controlled trials. Hypertension 2016;68:324-33.

102. Rosanoff A, Plesset MR. Oral magnesium supplements decrease high blood pressure (SBP>155 $\mathrm{mmHg}$ ) in hypertensive subjects on anti-hypertensive medications: a targeted meta-analysis. Magnes Res 2013;26:93-9.

103. Maier JA, Malpuech-Brugère $C$, Zimowska W, et al. Low magnesium promotes endothelial cell dysfunction: implications for atherosclerosis, inflammation and thrombosis. Biochim Biophys Acta 2004;1689:13-21

104. Ferrè $\mathrm{S}$, Baldoli $\mathrm{E}$, Leidi $\mathrm{M}$, et al. Magnesium deficiency promotes a pro-atherogenic phenotype in cultured human endothelial cells via activation of NFkB. Biochim Biophys Acta 2010;1802:952-8.

105. Shechter $M$. The role of magnesium as antithrombotic therapy. Wien Med Wochenschr 2000;150:343-7.

106. Briel RC, Lippert TH, Zahradnik HP. [Changes in blood coagulation, thrombocyte function and vascular prostacyclin synthesis caused by magnesium sulfate]. Geburtshilfe Frauenheilkd 1987;47:332-6.

107. Martindale L, Heaton FW. Magnesium deficiency in the adult rat. Biochem J 1964;92:119-26.

108. Battifora $\mathrm{H}$, Eisenstein $\mathrm{R}$, Laing $\mathrm{GH}$, et al. The kidney in experimental magnesium deprivation. a morphologic and biochemical study. Am J Pathol 1966;48:421-37.

109. Heggtveit HA, Herman L, Mishra RK. Cardiac necrosis and calcification in experimental magnesium deficiency. A light and electron microscopic study. Am J Pathol 1964;45:757-82.

110. Hruby A, O'Donnell CJ, Jacques PF, et al. Magnesium intake is inversely associated with coronary artery calcification: the Framingham Heart Study. JACC Cardiovasc Imaging 2014;7:59-69.

111. Shechter M, Sharir M, Labrador MJ, et al. Oral magnesium therapy improves endothelial function in patients with coronary artery disease. Circulation 2000;102:2353-8.

112. Nakamura M, Torii S, Hiramatsu M, et al. Dietary effect of magnesium on cholesterol-induced atherosclerosis of rabbits. $J$ Atheroscler Res 1965;5:145-58.

113. King JL, Miller RJ, Blue JP, et al. Inadequate dietary magnesium intake increases atherosclerotic plaque development in rabbits. Nutr Res 2009;29:343-9.

114. Kartha CC, Eapen JT, Radhakumary C, et al. Pattern of cardiac fibrosis in rabbits periodically fed a magnesium-restricted diet and administered rare earth chloride through drinking water. Biol Trace Elem Res 1998;63:19-30.

115. Vitale JJ, Velez H, Guzman C, et al. Magnesium deficiency in the Cebus monkey. Circ Res 1963;12:642-50.

116. Sherer $Y$, Shoenfeld $Y$, Shaish A, et al. Suppression of atherogenesis in female low-density lipoprotein receptor knockout mice following magnesium fortification of drinking water: the importance of diet. Pathobiology 2000;68:93-8.

117. Sherer $Y$, Shaish A, Levkovitz $\mathrm{H}$, et al. Magnesium fortification of drinking water suppresses atherogenesis in male LDL-receptordeficient mice. Pathobiology 1999;67:207-13.

118. Rasmussen HS, Aurup P, Goldstein K, et al. Influence of magnesium substitution therapy on blood lipid composition in patients with ischemic heart disease. A double-blind, placebo controlled study. Arch Intern Med 1989;149:1050-3.

119. Gupta BK, Glicklich D, Tellis VA. Magnesium repletion therapy improved lipid metabolism in hypomagnesemic renal transplant recipients: a pilot study. Transplantation 1999;67:1485-7.

120. Cojocaru IM, Cojocaru M, Burcin C, et al. Serum magnesium in patients with acute ischemic stroke. Rom J Intern Med 2007;45:269-73.

121. Driessens FC, Verbeeck RM. On the prevention and treatment of calcification disorders of old age. Med Hypotheses 1988;25:131-7.

122. Ito M, Toda T, Kummerow FA, et al. Effect of magnesium deficiency on ultrastructural changes in coronary arteries of swine. Acta Patho Jpn 1986;36:225-34.

123. Ahmad A, Bloom S. Sodium pump and calcium channel modulation of Mg-deficiency cardiomyopathy. Am J Cardiovasc Pathol 1989;2:277-83.

124. Bussière L, Mazur A, Gueux E, et al. Triglyceride-rich lipoproteins from magnesium-deficient rats are more susceptible to oxidation by cells and promote proliferation of cultured vascular smooth muscle cells. Magnes Res 1995;8:151-7.

125. Ryzen E, Elkayam U, Rude RK. Low blood mononuclear cell magnesium in intensive cardiac care unit patients. Am Heart $J$ 1986;111:475-80.

126. Whang R, Hampton EM, Whang DD. Magnesium homeostasis and clinical disorders of magnesium deficiency. Ann Pharmacother 1994;28:220-6

127. Kubena KS, Durlach J. Historical review of the effects of marginal intake of magnesium in chronic experimental magnesium deficiency. Magnes Res 1990;3:219-26.

128. Klevay LM, Milne DB. Low dietary magnesium increases supraventricular ectopy. Am J Clin Nutr 2002;75:550-4.

129. Nielsen FH, Milne DB, Klevay LM, et al. Dietary magnesium deficiency induces heart rhythm changes, impairs glucose tolerance, and decreases serum cholesterol in post menopausa women. J Am Coll Nutr 2007;26:121-32.

130. Sasaki S, Oshima T, Matsuura $\mathrm{H}$, et al. Abnormal magnesium status in patients with cardiovascular diseases. Clin Sci 2000;98:175-81.

131. Chipperfield B, Chipperfield JR. Magnesium and the heart. Am Heart J 1977;93:679-82.

132. Papaceit J, Moral V, Recio J, et al. [Severe heart arrhythmia secondary to magnesium depletion. Torsade de pointes]. Rev Esp Anestesiol Reanim 1990;37:28-31.

133. Iseri LT. Role of magnesium in cardiac tachyarrhythmias. Am J Cardiol 1990;65:K47-K50.

134. Torshin IY, Gromova OA, Kalacheva AG, et al. [Meta-analysis of clinical trials of cardiovascular effects of magnesium orotate]. Ter Arkh 2015;87:88-97.

135. Raghu C, Peddeswara Rao P, Seshagiri Rao D. Protective effect of intravenous magnesium in acute myocardial infarction following thrombolytic therapy. Int J Cardiol 1999;71:209-15.

136. Serebruany VL, Herzog WR, Edenbaum LR, et al. Changes in the haemostatic profile during magnesium deficiency in swine. Magnes Res 1996;9:155-63

137. Nadler JL, Buchanan T, Natarajan R, et al. Magnesium deficiency produces insulin resistance and increased thromboxane synthesis. Hypertension 1993;21:1024-9.

138. Soma M, Cunnane SC, Horrobin DF, et al. Effects of low magnesium diet on the vascular prostaglandin and fatty acid metabolism in rats. Prostaglandins 1988;36:431-41.

139. Maurat JP, Kantelip JP, Anguenot T, et al. [Cardiovascular pathology and magnesium]. Therapie 1993;48:599-607.

140. Shechter M, Merz CN, Rude RK, et al. Low intracellular magnesium levels promote platelet-dependent thrombosis in patients with coronary artery disease. Am Heart J 2000;140:212-8.

141. Gawaz M, Ott I, Reininger AJ, et al. Effects of magnesium on platelet aggregation and adhesion. Magnesium modulates surface expression of glycoproteins on platelets in vitro and ex vivo. Thromb Haemost 1994;72:912-8. 
142. Mussoni L, Sironi L, Tedeschi L, et al. Magnesium inhibits arterial thrombi after vascular injury in rat: in vivo impairment of coagulation. Thromb Haemost 2001;86:1292-5.

143. Wannasilp N, Poungvarin N, Pokum S, et al. Serum magnesium in Thai coronary artery disease patients. J Med Assoc Thai 2001;84(Suppl 3):S645-9.

144. Rasmussen HS, McNair P, Gøransson L, et al. Magnesium deficiency in patients with ischemic heart disease with and without acute myocardial infarction uncovered by an intravenous loading test. Arch Intern Med 1988;148:329-32.

145. Sutton RA, Domrongkitchaiporn S. Abnormal renal magnesium handling. Miner Electrolyte Metab 1993;19:232-40.

146. Tuso PJ, Nortman D. Renal magnesium wasting associated with acetaminophen abuse. Conn Med 1992;56:421-3.

147. Delva P, Pastori C, Degan M, et al. Intralymphocyte free magnesium in patients with primary aldosteronism: aldosterone and lymphocyte magnesium homeostasis. Hypertension 2000;35:113-7.

148. Lalor BC, France MW, Powell D, et al. Bone and mineral metabolism and chronic alcohol abuse. Q J Med 1986;59:497-511.

149. Mountokalakis TD. Effects of aging, chronic disease, and multiple supplements on magnesium requirements. Magnesium 1987:6:5-11.

150. Fernández-Fernández FJ, Sesma P, Caínzos-Romero T, et al. Intermittent use of pantoprazole and famotidine in severe hypomagnesaemia due to omeprazole. Neth J Med 2010;68:329-30.

151. Lipner A. Symptomatic magnesium deficiency after small-intestinal bypass for obesity. Br Med J 1977;1:148.

152. Johnson S. The multifaceted and widespread pathology of magnesium deficiency. Med Hypotheses 2001;56:163-70.

153. Lum G. Hypomagnesemia in acute and chronic care patient populations. Am J Clin Pathol 1992;97:827-30.

154. Rujner J, Socha J, Wojtasik A, et al. [Magnesium status in children and adolescents with celiac disease]. Wiad Lek 2001;54:277-85.

155. Normén L, Arnaud MJ, Carlsson NG, et al. Small bowel absorption of magnesium and calcium sulphate from a natural mineral water in subjects with ileostomy. Eur J Nutr 2006;45:105-12.

156. Takase B, Akima T, Uehata A, et al. Effect of chronic stress and sleep deprivation on both flow-mediated dilation in the brachial artery and the intracellular magnesium level in humans. Clin Cardiol 2004;27:223-7.

157. Schilsky RL, Anderson T. Hypomagnesemia and renal magnesium wasting in patients receiving cisplatin. Ann Intern Med 1979;90:929-31.

158. Lam M, Adelstein DJ. Hypomagnesemia and renal magnesium wasting in patients treated with cisplatin. Am J Kidney Dis 1986;8:164-9.

159. Bianchetti MG, Kanaka C, Ridolfi-Lüthy A, et al. Chronic renal magnesium loss, hypocalciuria and mild hypokalaemic metabolic alkalosis after cisplatin. Pediatr Nephrol 1990;4:219-22.

160. Evans TR, Harper CL, Beveridge IG, et al. A randomised study to determine whether routine intravenous magnesium supplements are necessary in patients receiving cisplatin chemotherapy with continuous infusion 5-fluorouracil. Eur J Cancer 1995;31A:174-8.

161. Mashhadi MA, Heidari Z, Zakeri Z. Mild hypomagnesemia as the most common Cisplatin nephropathy in Iran. Iran J Kidney Dis 2013;7:23-7.

162. Main AN, Morgan RJ, Russell RI, et al. Mg deficiency in chronic inflammatory bowel disease and requirements during intravenous nutrition. JPEN J Parenter Enteral Nutr 1981;5:15-19.

163. Barton CH, Vaziri ND, Martin DC, et al. Hypomagnesemia and renal magnesium wasting in renal transplant recipients receiving cyclosporine. Am J Med 1987;83:693-9.

164. Nozue T, Kobayashi A, Kodama T, et al. Pathogenesis of cyclosporine-induced hypomagnesemia. J Pediatr 1992;120:638-40.

165. Millane T, Wilson AJ, Patel MK, et al. Mitochondrial calcium deposition in association with cyclosporine therapy and myocardial magnesium depletion: a serial histologic study in heart transplant recipients. J Heart Lung Transplant 1994;13:473-80.

166. Rob PM, Goebel Y, Lebeau A, et al. Myocardial magnesium depletion during cyclosporine treatment, associated with reciproca calcium overload, can be prevented by plentiful dietary magnesium supply. Clin Investig 1994;72:137.

167. Roffi M, Kanaka C, Mullis PE, et al. Hypermagnesiuria in children with newly diagnosed insulin-dependent diabetes mellitus. $A m \mathrm{~J}$ Nephrol 1994;14:201-6.

168. Revúsová V, Polakovicová D, Stefíková K, et al. [A decrease in magnesium in the serum and blood lymphocytes after intravenous infusion of glucose]. Cas Lek Cesk 1991;130:513-5.
169. Martin BJ, McAlpine JK, Devine BL. Hypomagnesaemia in elderly digitalised patients. Scott Med J 1988;33:273-4.

170. Diuretics in the elderly. Br Med J 1978;1:1484.

171. Zumkley $\mathrm{H}$, Losse $\mathrm{H}$, Spieker $\mathrm{C}$, et al. Effects of drugs on magnesium requirements. Magnesium 1987;6:12-17.

172. Cocco G, Iselin HU, Strozzi C, et al. Magnesium depletion in patients on long-term chlorthalidone therapy for essential hypertension. Eur J Clin Pharmacol 1987;32:335-8.

173. Joo Suk O. Paradoxical hypomagnesemia caused by excessive ingestion of magnesium hydroxide. Am J Emerg Med 2008;26:837. e1-837.e2.

174. Galland L. Magnesium, stress and neuropsychiatric disorders. Magnes Trace Elem 1991;10:287-301.

175. Blasco LM, Novo F, González-Fernández CR. Chronic cyclic nonnephrogenic magnesium depletion without losses. N Engl J Med 2012;366:1845-6.

176. Seelig MS. Increased need for magnesium with the use of combined oestrogen and calcium for osteoporosis treatment. Magnes Res 1990;3:197-215.

177. Kamble TK, Ookalkar DS. Lactational hypomagnesaemia. Lancet 1989;2:155-6

178. Drenick EJ, Hunt IF, Swendseid ME. Magnesium depletion during prolonged fasting of obese males. J Clin Endocrinol Metab 1969;29:1341-8.

179. Martin KJ, González EA, Slatopolsky E. Clinical consequences and management of hypomagnesemia. J Am Soc Nephrol 2009;20:2291-5.

180. Nanji AA, Denegri JF. Hypomagnesemia associated with gentamicin therapy. Drug Intell Clin Pharm 1984;18:596-8.

181. Zaloga GP, Chernow B, Pock A, et al. Hypomagnesemia is a common complication of aminoglycoside therapy. Surg Gynecol Obstet 1984;158:561-5.

182. Głuszek J, Raszeja-Wanic B, Grajek S, et al. [Magnesium deficiency in tubular acidosis]. Wiad Lek 1980;33:401-4.

183. Bianchetti MG, Oetliker $\mathrm{OH}$, Lütschg J. Magnesium deficiency in primary distal tubular acidosis. J Pediatr 1993;122:833.

184. Brannan PG, Vergne-Marini P, Pak CY, et al. Magnesium absorption in the human small intestine. Results in normal subjects, patients with chronic renal disease, and patients with absorptive hypercalciuria. J Clin Invest 1976;57:1412-8.

185. Ohtsuka S, Yamaguchi I. [Magnesium in congestive heart failure] Clin Calcium 2005;15:181-6.

186. Vitale $\mathrm{C}$, Marangella $\mathrm{M}$, Petrarulo $\mathrm{M}$, et al. [Mineral balance during hemodialysis and hemodiafiltration]. Minerva Urol Nefrol 1990;42:173-6.

187. Djurhuus MS, Skøtt P, Hother-Nielson O, et al. Insulin increases renal magnesium excretion: a possible cause of magnesium depletion in hyperinsulinaemic states. Diabet Med 1995;12:664-9.

188. Hwang DL, Yen CF, Nadler JL. Insulin increases intracellular magnesium transport in human platelets. J Clin Endocrinol Metab 1993:76:549-53.

189. Kodama N, Nishimuta M, Suzuki K. Negative balance of calcium and magnesium under relatively low sodium intake in humans. $J$ Nutr Sci Vitaminol 2003:49:201-9.

190. Sjögren A, Florén $\mathrm{CH}$, Nilsson A. Evaluation of magnesium status in Crohn's disease as assessed by intracellular analysis and intravenous magnesium infusion. Scand J Gastroenterol 1988;23:555-61.

191. Oralewska B, Zawadzki J, Jankowska I, et al. Disorders of magnesium homeostasis in the course of liver disease in children. Magnes Res 1996;9:125-8.

192. Rylander R, Tallheden T, Vormann J. Acid-base conditions regulate calcium and magnesium homeostasis. Magnes Res 2009;22:262-5.

193. Rylander R, Remer T, Berkemeyer S, et al. Acid-base status affects renal magnesium losses in healthy, elderly persons. $J$ Nutr 2006;136:2374-7

194. Ryzen E, Rude RK. Low intracellular magnesium in patients with acute pancreatitis and hypocalcemia. West J Med 1990;152:145-8.

195. Papazachariou IM, Martinez-Isla A, Efthimiou E, et al. Magnesium deficiency in patients with chronic pancreatitis identified by an intravenous loading test. Clin Chim Acta 2000;302:145-54

196. Liamis G, Gianoutsos C, Elisaf M. Acute pancreatitis-induced hypomagnesemia. Pancreatology 2001;1:74-6.

197. Bhardwaj P, Thareja S, Prakash S, et al. Micronutrient antioxidant intake in patients with chronic pancreatitis. Trop Gastroenterol 2004;25:69-72.

198. Markell MS, Altura BT, Sarn Y, et al. Deficiency of serum ionized magnesium in patients receiving hemodialysis or peritoneal dialysis. Asaio J 1993;39:M801-4

199. Shabajee N, Lamb EJ, Sturgess I, et al. Omeprazole and refractory hypomagnesaemia. BMJ 2008;337:a425. 
200. Mackay JD, Bladon PT. Hypomagnesaemia due to proton-pump inhibitor therapy: a clinical case series. QJM 2010;103:387-95.

201. Stendig-Lindberg G, Shapiro Y, Epstein Y, et al. Changes in serum magnesium concentration after strenuous exercise. J Am Coll Nutr 1987;6:35-40.

202. Spasov AA, lezhitsa IN, Kravchenko MS, et al. Features of central neurotransmission in animals in conditions of dietary magnesium deficiency and after its correction. Neurosci Behav Physiol 2009;39:645-53.

203. Hanna S. Influence of large doses of vitamin D on magnesium metabolism in rats. Metabolism 1961;10:735-43.

204. Grobin W. A New Syndrome, Magnesium-Deficiency Tetany. Can Med Assoc J 1960;82:1034-5.

205. Gerst PH, Porter MR, Fishman RA. Symptomatic magnesium deficiency in surgical patients. Ann Surg 1964;159:402-6.

206. Alloui A, Begon S, Chassaing C, et al. Does Mg2+ deficiency induce a long-term sensitization of the central nociceptive pathways? Eur J Pharmacol 2003;469:65-9.

207. Durlach J, Pagès N, Bac P, et al. Headache due to photosensitive magnesium depletion. Magnes Res 2005;18:109-22.

208. Cevette MJ, Barrs DM, Patel A, et al. Phase 2 study examining magnesium-dependent tinnitus. Int Tinnitus J 2011;16:168-73.

209. Agarwal R, lezhitsa IN, Agarwal P, et al. Mechanisms of cataractogenesis in the presence of magnesium deficiency. Magnes Res 2013;26:2-8.

210. Mccoy JH, Kenney MA. Depressed immune response in the magnesium-deficient rat. J Nutr 1975;105:791-7.

211. Siwek M, Wróbel A, Dudek D, et al. The role of copper and magnesium in the pathogenesis and treatment of affective disorders]. Psychiatr Pol 2005;39:911-20.

212. Cevette MJ, Vormann J, Franz K. Magnesium and hearing. J Am Acad Audiol 2003;14:202-12.

213. Kitliński M, Stepniewski M, Nessler J, et al. Is magnesium deficit in lymphocytes a part of the mitral valve prolapse syndrome? Magnes Res 2004;17:39-45.

214. Rude RK, Oldham SB, Singer FR. Functional hypoparathyroidism and parathyroid hormone end-organ resistance in human magnesium deficiency. Clin Endocrinol 1976;5:209-24

215. Jooste PL, Wolfswinkel JM, Schoeman JJ, et al. Epileptic-type convulsions and magnesium deficiency. Aviat Space Environ Med 1979;50:734-5.

216. Spisák V. [Magnesium loading test in cardiovascular diseases]. Vnitr Lek 1992;38:337-44.

217. de Lordes Lima M, Cruz T, Pousada JC, et al. The effect of magnesium supplementation in increasing doses on the control of type 2 diabetes. Diabetes Care 1998;21:682-6.

218. Hosseini JM, Niemela JE, Elin RJ. Mononuclear blood cell magnesium in older subjects: evaluation of its use in clinical practice. Ann Clin Biochem 1995;32(Pt 4):435.
219. Lim P, Jacob E, Dong S, et al. Values for tissue magnesium as a guide in detecting magnesium deficiency. J Clin Pathol 1969;22:417-21.

220. Solarska K, Stepniewski M, Pach J. Concentration of magnesium in hair of inhabitants of down-town Kraków, the protective zone of Steel-Mill "Huta im. Sendzimira" and Tokarnia village. Przegl Lek 1995;52:263-6.

221. Kozielec T, Sałacka A, Radomska K, et al. The influence of magnesium supplementation on magnesium and calcium concentrations in hair of children with magnesium shortage. Magnes Res 2001;14:33-8.

222. Durlach J, Pagès N, Bac $\mathrm{P}$, et al. Importance of the ratio between ionized and total Mg in serum or plasma: new data on the regulation of $\mathrm{Mg}$ status and practical importance of total $\mathrm{Mg}$ concentration in the investigation of $\mathrm{Mg}$ imbalance. Magnes Res 2002;15:203-5.

223. Rude RK, Stephen A, Nadler J. Determination of red blood cell intracellular free magnesium by nuclear magnetic resonance as an assessment of magnesium depletion. Magnes Trace Elem 1991:10:117-21.

224. Markell MS, Altura BT, Barbour RL, et al. lonized and total magnesium levels in cyclosporin-treated renal transplant recipients: relationship with cholesterol and cyclosporin levels. Clin Sci 1993;85:315-8.

225. Thomas J, Millot JM, Sebille S, et al. Free and total magnesium in lymphocytes of migraine patients - effect of magnesium-rich mineral water intake. Clin Chim Acta 2000;295:63-75.

226. Elisaf M, Panteli K, Theodorou J, et al. Fractional excretion of magnesium in normal subjects and in patients with hypomagnesemia. Magnes Res 1997;10:315-20.

227. Nadler JL, Malayan $\mathrm{S}$, Luong $\mathrm{H}$, et al. Intracellular free magnesium deficiency plays a key role in increased platelet reactivity in type II diabetes mellitus. Diabetes Care 1992:15:835-41.

228. Toto KH, Yucha CB. Magnesium: homeostasis, imbalances, and therapeutic uses. Crit Care Nurs Clin North Am 1994;6:767-83.

229. Van Hook JW. Endocrine crises. Hypermagnesemia. Crit Care Clin 1991;7:215-23.

230. Salem M, Kasinski N, Munoz R, et al. Progressive magnesium deficiency increases mortality from endotoxin challenge: protective effects of acute magnesium replacement therapy. Crit Care Med 1995;23:108-18.

231. Whang R. Clinical disorders of magnesium metabolism. Compr Ther 1997;23:168-73.

232. Amighi J, Sabeti S, Schlager O, et al. Low serum magnesium predicts neurological events in patients with advanced atherosclerosis. Stroke 2004;35:22-7.

233. Gottlieb SS. Importance of magnesium in congestive heart failure. Am J Cardiol 1989;63:G39-G42. 


\section{Correction: Subclinical magnesium deficiency: a principal driver of cardiovascular disease and a public health crisis}

DiNicolantonioJJ, O'Keefe JH, Wilson W. Subclinical magnesium deficiency: a principal driver of cardiovascular disease and a public health crisis. Open Heart 2018;5:e006668. doi: 10.1136/openhrt-2017-000668.

The following sentence in the abstract 'Certain individuals will need to supplement with magnesium in order to prevent suboptimal magnesium deficiency, especially if trying to obtain an optimal magnesium status to prevent chronic disease.' should be: 'Certain individuals will need to supplement with magnesium in order to prevent subclinical magnesium deficiency, especially if trying to obtain an optimal magnesium status to prevent chronic disease.'

Open Access This is an Open Access article distributed in accordance with the Creative Commons Attribution Non Commercial (CC BY-NC 4.0) license, which permits others to distribute, remix, adapt, build upon this work non-commercially, and license their derivative works on different terms, provided the original work is properly cited and the use is non-commercial. See: http:// creativecommons.org/licenses/by-nc/4.0/

Open Heart 2018;5:e000668corr1. doi:10.1136/openhrt-2017-000668corr1

A) Check for updates 